\title{
Phoenicians in Southern Crete
}

\author{
JOSEPH W. SHAW
}

\begin{abstract}
During the 1979 excavation season at Kommos, a curious structure with three tapering stone pillars was discovered on the floor of a Geometric/Archaic temple, above which lay a fourth-century B.C. Greek temple. The tripillar structure appears to have been a center of worship particularly in the late ninth and eighth centuries B.C. Its appearance and certain historical and archaeological indications suggest that it may have been inspired by Phoenician shrines, if not set up by Phoenician seafarers visiting Kommos.
\end{abstract}

During the second millennium B.C. Kommos, for which the ancient name remains unknown, was a Minoan seaside settlement with large ashlar buildings built near the shore (figs. 1 and 2, where the lighter and most of the shaded walls are Minoan; the solid walls are Greek). ${ }^{1}$ In the next millennium, following the Minoan period, the use of the area changed, from a residential and civic center to a religious one represented by a small rural sanctuary built upon a Minoan ashlar structure. Of its three major temple phases, the first began (ca. 925-800 B.C.) with the establishment of a small rectangular temple (A), open to the east, possibly with benches on the interior. Temple A was succeeded (ca. 800-600 B.C.) on the same site by Temple B (fig. 3), which, after a hiatus of some 200 years, was itself covered over by Temple C (fig. 1, top left, and 2, at A2). The sanctuary gradually grew with the addition of numerous other buildings and it was also provided with four altars set symmetrically in an open court (ca. 400

${ }^{1}$ The circumstances of discovery were first described in J.W. Shaw, "Excavations at Kommos (Crete) during 1979," Hesperia 49 (1980) 229-37, 245-48 where there is also a preliminary suggestion of a Phoenician connection. A more complete public presentation was made in San Antonio, Texas, in December of 1986, during the annual AIA/APA convention (AJA 91 [1987] 297). I would like to express my gratitude to Douglas Orr, the trenchmaster for the original probe below the later temple floor; to John McEnroe who placed the shrine in its proper architectural setting by excavating the eastern half of Temple B (Hesperia 50 [1981] 230-36, 250-51); and to Maria C. Shaw, who not only first realized that the shrine lay within an earlier building but who helped edit the text and with whom I have discussed many aspects of this presentation, as I did also with Peter Callaghan, who by studying the pottery has provided the chronological framework for the Greek levels.

Much of the research was done during 1982-1983 when I was Special Research Professor at the American School of
B.C.-A.D. 150). Animal sacrifice, feasting and the offering of figurines (especially bulls) were common to all three temple periods. Inscriptions from a later phase of $\mathrm{C}$ mention Zeus, Athena, and probably Poseidon; but the nature of the deities worshipped becomes progressively more vague as one investigates earlier temple phases.

The intermediary Temple B, with which we are primarily concerned in this study, had its east side open, and the entrance was marked by a pillar at the center of the eastern side supporting a presumably flat roof (figs. 3, 5, and 6 , at a). During the first of its three phases a long, narrow platform existed along its northern wall (fig. 6, at b) and probably the southern wall as well. This bench was probably used to accommodate seated celebrants, but offerings may also have been placed on it. Within the temple and along its axis were hearths in all periods. An exterior altar, as well as the interior hearths just mentioned, was used to burn the gods' portions of sacrifices, usually the tails and/or feet of the sacrificed goats and sheep.

\section{THE TRIPILLAR SHRINE}

During the first and second phases of Temple B a most unusual structure (figs. 4, 5, 7-10) served as the focus for worship. It was set about two-thirds of the way back from the entrance. Originally it consisted of four parts, the largest a roughly triangular sandstone block, apparently reused from an earlier Minoan structure, ${ }^{2}$ set flat on the temple's floor (at level $+4.54 \mathrm{~m}$ ), with the finished face of

Classical Studies at Athens. The excavation itself has been sponsored by the University of Toronto and the Royal Ontario Museum under the auspices of the American School of Classical Studies at Athens, and with financial support from the Social Sciences and Humanities Research Council of Canada, the SCM Corporation, as well as both private and corporate sources.

For preliminary reports concerned with Temple B, see Hesperia 49 (1980) 207-50 (= Kommos 1979); 50 (1981) 211-51 (= Kommos 1980); 51 (1982) 164-95 (= Kommos 1981); 53 (1984) 251-87 (= Kommos 1982-1983); 55 (1986) 219-69 (= Kommos 1984-1985).

2 The triangular block form is typical of the Late Minoan I ashlar buildings. This particular block may well have come from Building $\mathrm{J}$ to the west where such blocks were probably visible in the eroded scarp when Temple B was built (cf. Kommos 1980, pl. 52a, far left and right). In the following descriptions measurements are usually omitted, but they can be ascertained from the drawings. In earlier 


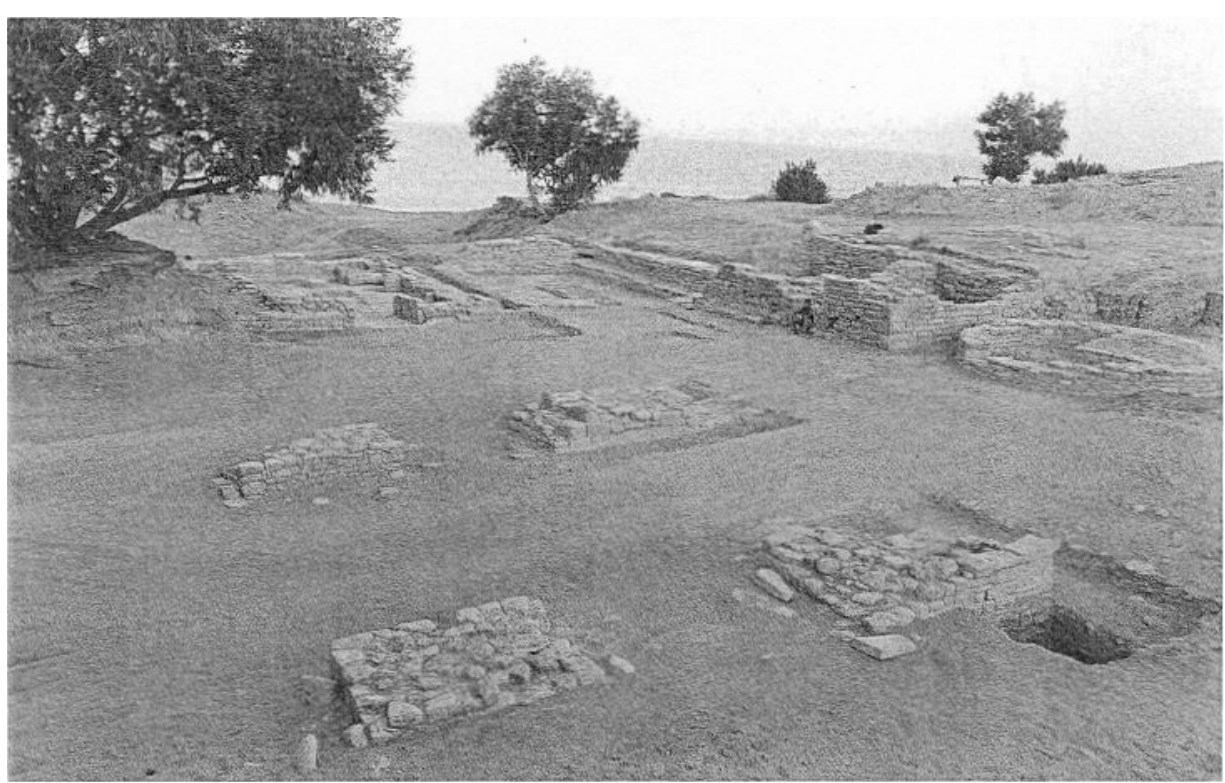

Fig. 1. Kommos sanctuary, general view looking west

the block facing the entrance. The block served as the base for three upright pillars. These were secured into the top of the block by means of sockets set ca. $0.27 \mathrm{~m}$ back from the stone's edge. ${ }^{3}$ Of these only two are visible, cut with their eastern edges in line (fig. 9, right). The

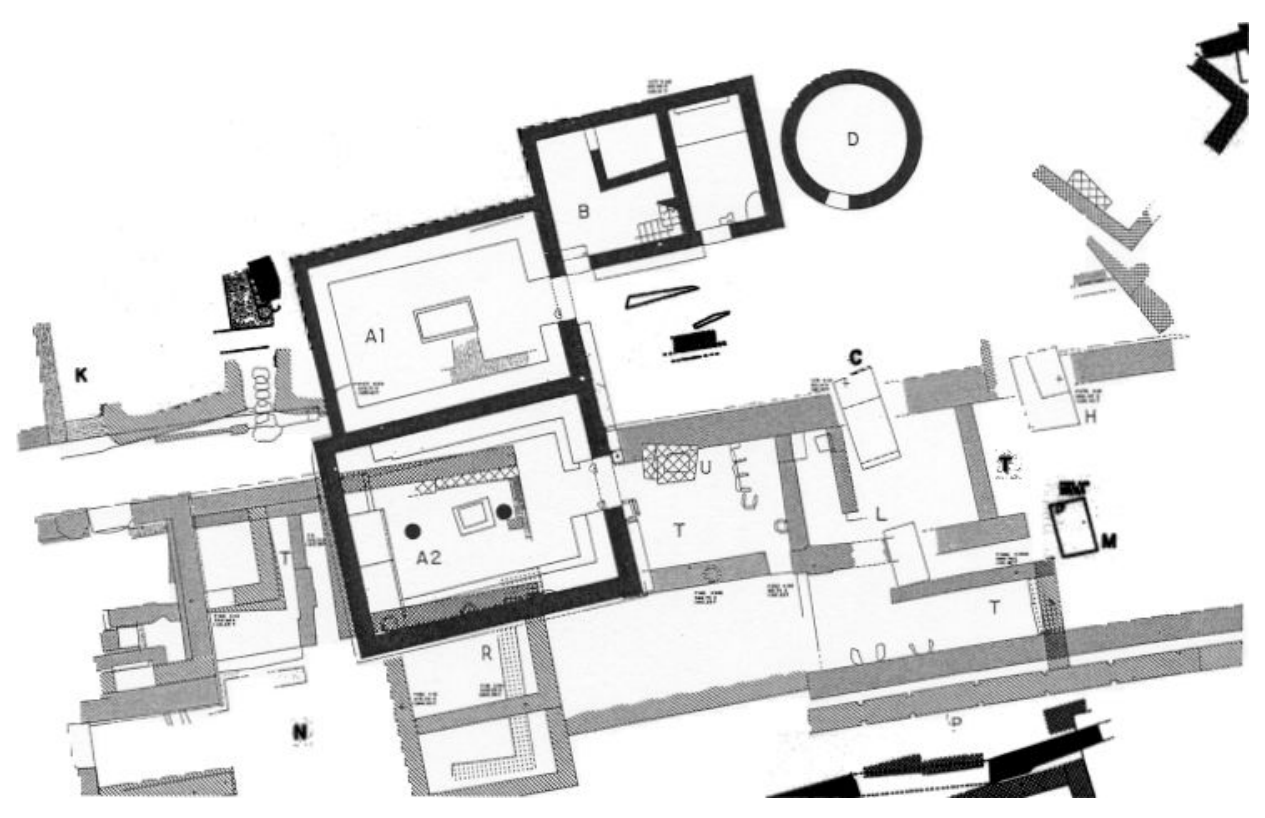

Fig. 2. Kommos, schematic plan of portion of southern area, showing the latest temple buildings (Al-2, B, D) and altars $(\mathrm{C}, \mathrm{H}$, L, M) above Minoan remains. (G. Bianco)

interpretations of the shrine (e.g., Kommos 1979, 248), the seventh-century sculpture and associated material presumably provided its date. Here I suggest that the shrine was installed earlier when Temple B was built during the eighth century.

${ }^{3}$ The cutting for the northern pillar was never seen since in order to remove it we would have been forced to raise the western column base of Temple $\mathrm{C}$, seen in the upper center of figs. 7-8. Aside from our removing C's floor slabs in order to excavate B, we did not disturb any of C's other features (e.g., statue base, hearth, benches). 

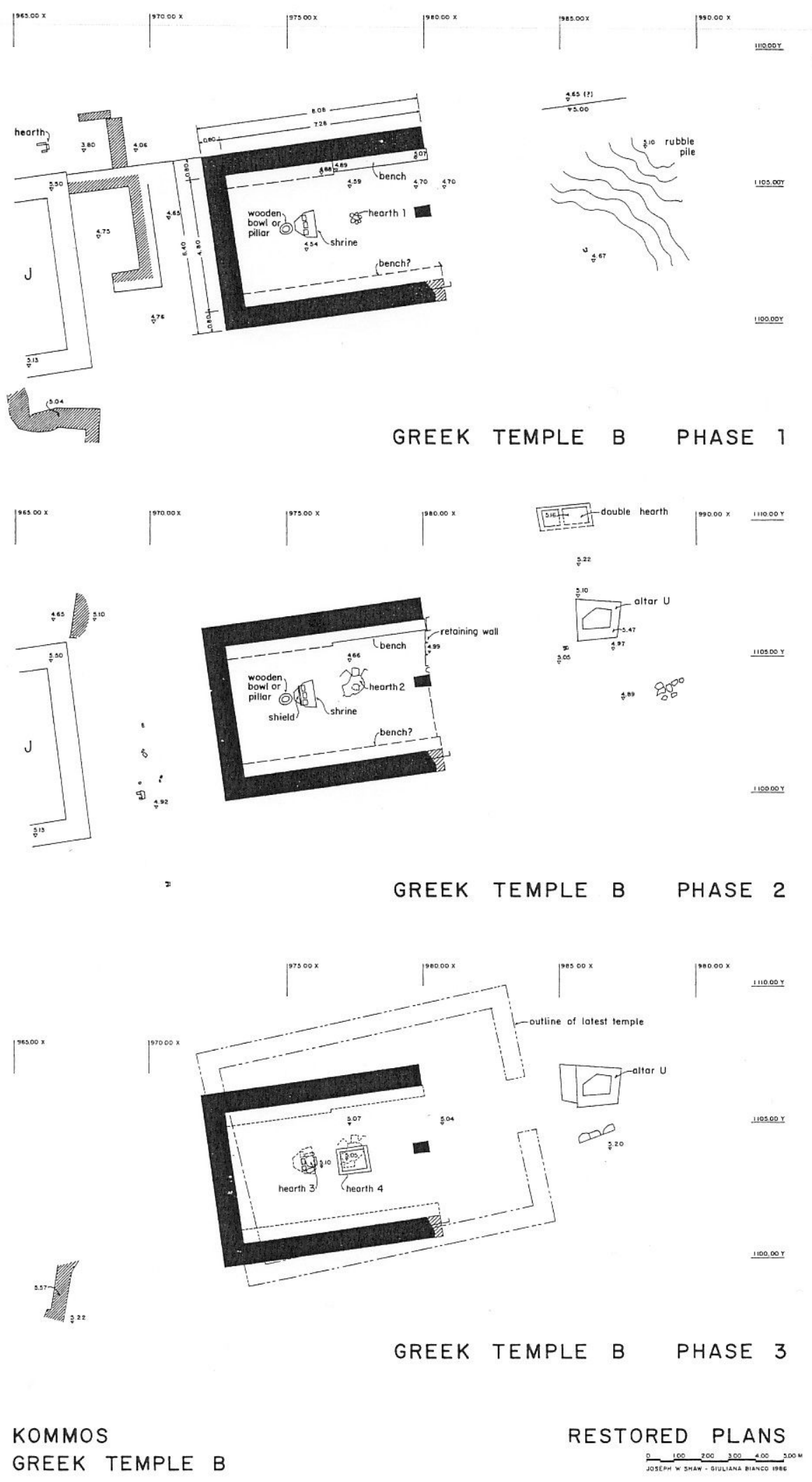

Fig. 3. The three major phases of Temple B at Kommos. (J. Shaw and G. Bianco) 


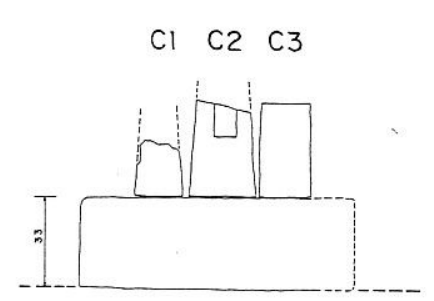

ELEVATION

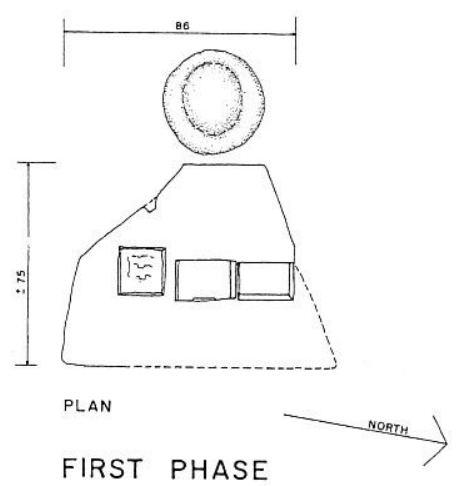

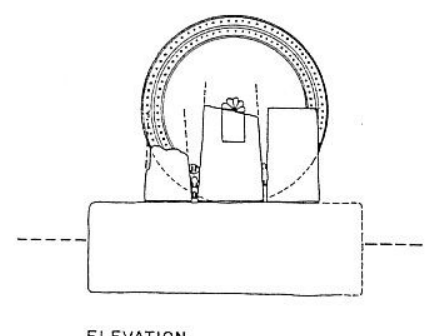

ELEVATION

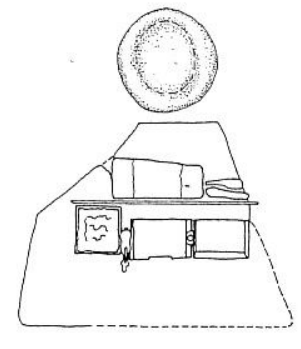

PLAN

SECOND PHASE

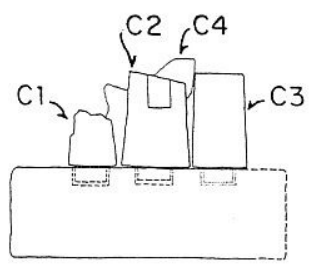

ELEVATION

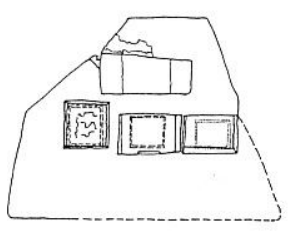

PLAN

SECOND PHASE

without offerings
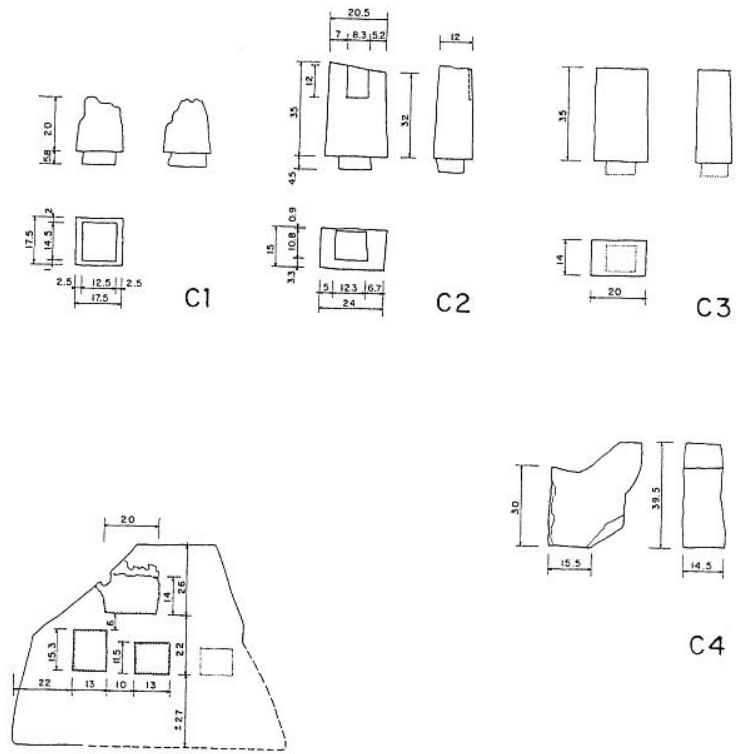

C4

PLAN

SHRINE DETAILS

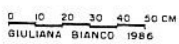

Fig. 4. Phases and details of tripillar shrine. (J. Shaw and G. Bianco) 

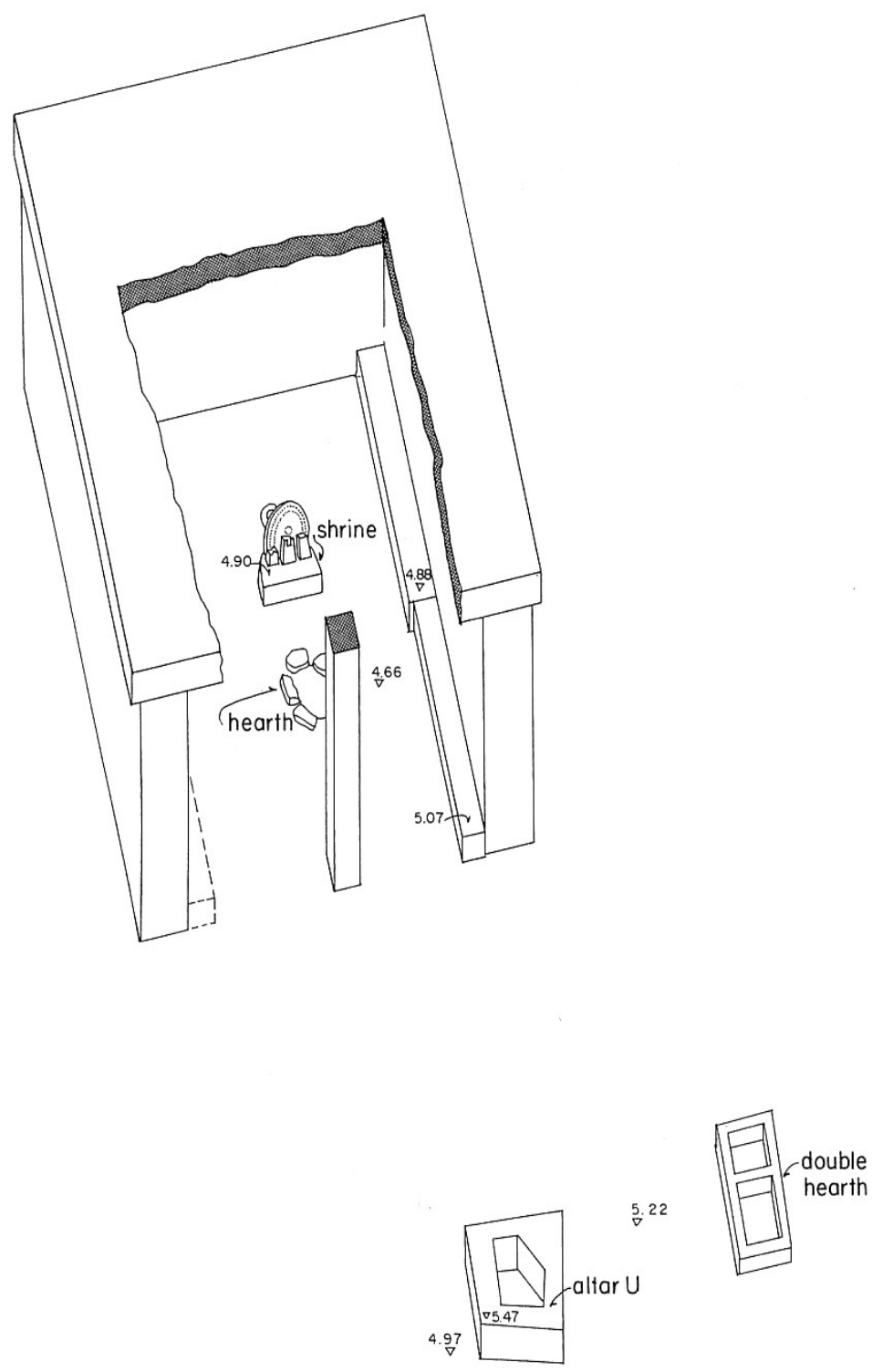

GREEK TEMPLE B

KOMMOS

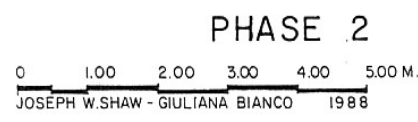

PHASE 2

JOSEPH W.SHAW - GIULIANA BIANCO 1988

Fig. 5. Isometric view of Temple B. phase 2. (J. Shaw and G. Bianco)

southern socket is significantly larger than its neighbor, for no apparent reason.

The southernmost pillar is square in section and stubby ( $0.175 \mathrm{~m}$ wide at its base and only $0.20 \mathrm{~m}$ high). Its somewhat rough upper surface suggests it may once have continued up further, but how far cannot 


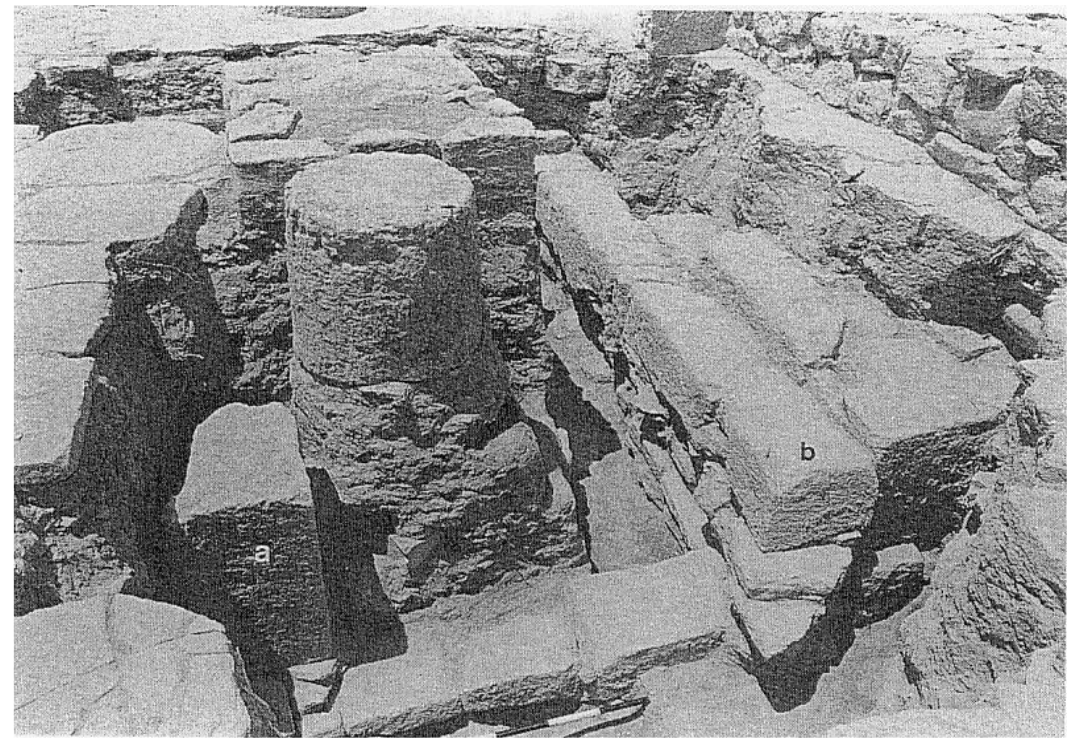

Fig. 6. Temple B, view of sounding at entrance on eau, showing central pillar (a) and northern bench (b)

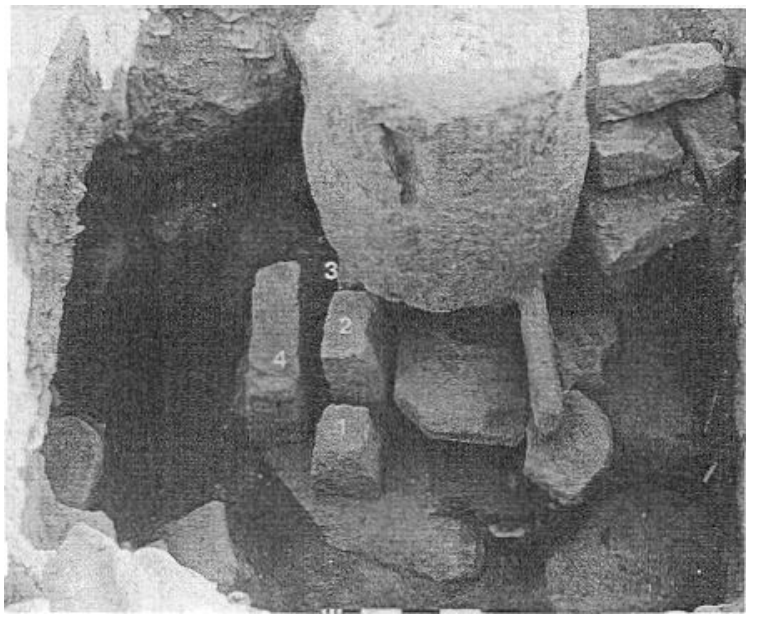

Fig. 7. Temple B, tripillar shrine before removal of pillars (left) below later hearth (right) and column base (top). Burnt wooden bowl to far left.

not be ascertained (fig.7). ${ }^{4}$ The central pillar (fig. 10), 0.24 $\mathrm{m}$ wide and $0.15 \mathrm{~m}$ thick at its base, tapers only as seen from the front or back, unlike the southern example which tapers on all sides. An enigmatic shallow vertical cutting $0.083 \mathrm{~m}$ wide began $0.23 \mathrm{~m}$ above the base of the pillar. The cutting contained no trace of color or decoration. It may always have been plain; it may have once been painted; or a thin plaque may have been set into it. The

4 The description in Kommos 1979, 234 should be altered to read that there is "little trace of fresh breakage" on the pillars. The most likely time for such breakage, with the rough

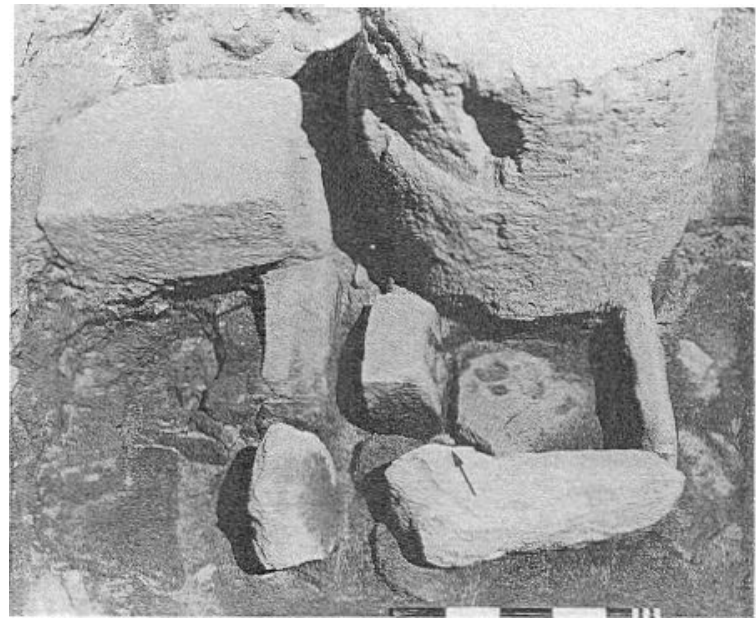

Fig. 8. Temple B, later hearth superposed above tripillar shrine, with head of bronze horse at arrow

cutting is too shallow to have served to anchor anything substantial. To judge from its uneven upper surface, this central pillar probably was broken off in antiquity. The third, northern pillar, on the other hand, seems complete.

Behind what we might refer to henceforth as the "tripillar shrine" was a curious wooden feature set in the floor. The remains give the impression of an oval

edges later smoothed somewhat through use, is when the central pillar may have been evened off during Phase 3 (for which, see below) to conform to the top of the hearth. 
wooden bowl, $0.25-0.34 \mathrm{~m}$ in inner diameter and $0.26 \mathrm{~m}$ deep, its top even with that of the triangular slab base. ${ }^{5}$ It was found filled with the clayish soil which characterizes the overlying stratum. It is quite charred, which explains its preservation. If not a bowl it might be the stump of a wooden pillar that was burned. If so it may have served the same structural function that the western stone column of Temple $\mathrm{C}$ built nearby did in the later building. ${ }^{6}$ Or, if a short column, it could be the support for a bowl, chalice, or tabletop. One must also explain, in any case, how the stump was burned in such a way that its top became quite evenly hollowed out. If we are dealing, on the other hand, with a wooden bowl, then it was perhaps $0.30 \mathrm{~m}$ high and placed upon the first floor of the temple, perhaps to receive liquid offerings, although it seems curious that a wooden receptacle would be chosen for such a purpose. This again would not explain the burning.

In seeking a practical explanation for the tripillar structure, the possibility that the pillars were used to support a flat object, such as a tabletop, must be eliminated, for they are uneven in height and set in a straight line, rather than in tripod fashion. Nor, apparently, were the pillars provided with means for attachments, as in the case of a Cypriot example, for which the attachment of a mask has been suggested (fig. 14, and see below). Rather, the only viable alternative seems to be that the pillars were freestanding, as we see them in Figure 4. The pillars were not found with accompanying furniture, although they may have once been surrounded by figurines and other votive objects such as those found in front of them. ${ }^{7}$ On the other hand, the symbolism of the pillars was no doubt understood by the worshippers (see below).

It is important to follow first the history of the use of the shrine. Sometime after ca. 750 B.C., during the second phase of Temple B, a shield, $0.69 \mathrm{~m}$ in diameter, was placed behind the pillars (figs. 3.2, 5), inferred from the discovery of circular bronze strips, decorated with bosses in repoussé, which were once fastened to a wooden and leather framework. The strips were scattered around and in back (west side) of

${ }^{5}$ Since the top of the "bowl" is only $0.33 \mathrm{~m}$ above B's first floor, and the interior of the bowl is $0.26 \mathrm{~m}$ deep, the bottom of the bowl must reach down at least to the floor. Because of the cramped conditions within the original sounding (Trench 29A1), however, and our desire to study and then cover over the remains before the fall rains, we did not make a section alongside the bowl, the top of which can be seen dearly in Kommos 1979, pl. $63 \mathrm{~b}$. Had we done so its form and, therefore, function might be dearer.

6 We might have here, therefore, the structural predecessor to the arrangement of columns within the later Cretan temples at Dreros, Prinias (Temple A) and, of course, in Kommos's own Temple C.

${ }^{7}$ Kommos 1979, 233.

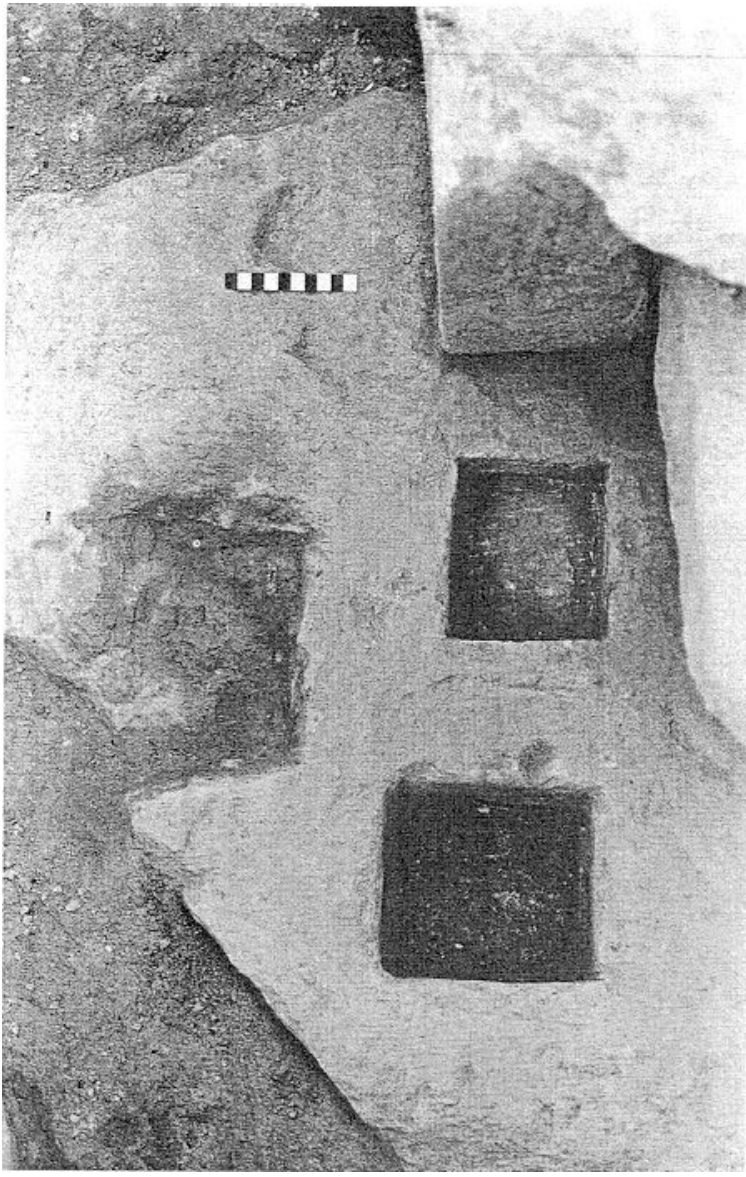

Fig. 9. Temple B, shrine after removal of two pillars, showing two original mortises (right) and irregular, later cutting (left)

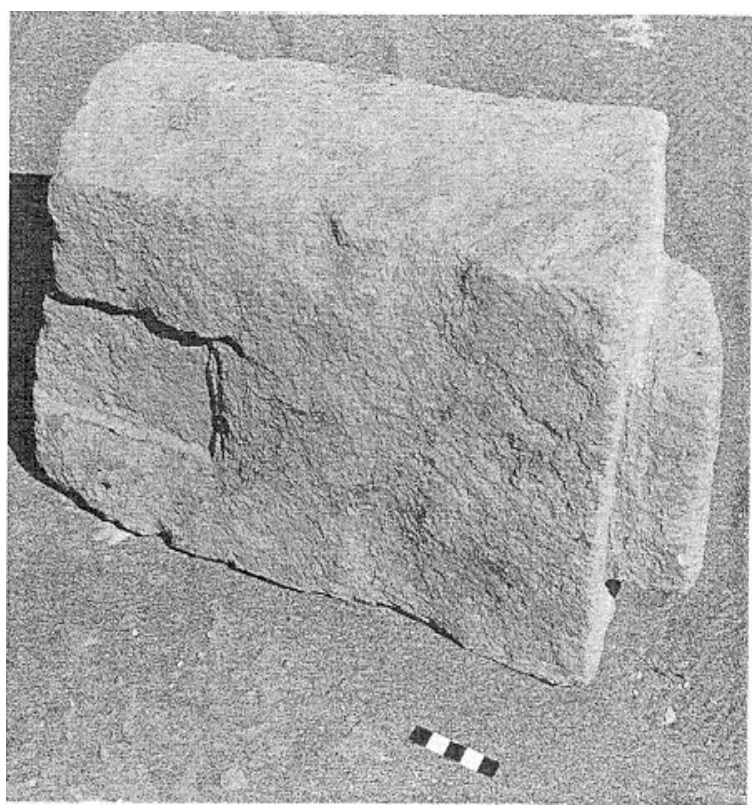

Fig. 10. Temple B, central pillar of shrine after removal 
the shrine and at the level of the later floor. An irregular slab (fig. 4, C4, lower right; fig. 7, on the left), the lower, unshaped portion of which was set into a roughly rectangular depression cut into the triangular stone base of the pillars, is a good candidate for propping up the shield (fig. 7, left).' Also, during this later phase, a bronze figurine of a horse was positioned between the two southern pillars, facing east (figs. 4, 8, at arrow). Oddly, a fine Egyptian faience figurine of the war-goddess Sekhmet was then placed on top of the horse, contrasting with the Greek style of the horse.' Both Sekhmet and the horse were firmly wedged between the pillars, a position designed to make their removal difficult, as the temple was apparently open and subject to pillaging by passersby. Between the central and northern pillar another faience figurine, a standing male, was set, possibly to be identified as Nefertum, son of Sekhmet, and the second of the Memphite triad of Sekhmet, Nefertum, and Ptah. Numerous other offerings were found upon the base slab next to the pillars.

Toward the end of the third phase of Temple B the floor level gradually rose and the 'bowl' and the original bench, or benches, were covered over. The upper parts of the three pillars were then incorporated into the western side of a hearth found filled with bone and ash (fig. 3, hearth 3 ; fig. 8). ${ }^{\circ}$ The area to the west continued to attract occasional offerings, but, after a transitional period during which local Cretan and Aegean goods were offered, the pillars were finally covered. Some ritual associated with the sanctuary continued to be observed, as the evidence for feasting, sacrifice, and the dedication of animal figurines indicates.

\section{PILLAR WORSHIP}

\section{The Aegean}

In order to understand the tripillar shrine at Kommos, one needs to turn to examples found in religious contexts in other cultures. The use of sacred stones and pillars, large and small, single and multiple, to represent deities, or to serve as a home for them, is known in various cultures, and in particular in certain areas of the Eastern

${ }^{8}$ The irregularity of the cutting, the form and setting of this slab, and the date of the accompanying offerings summarized in the text all suggest that slab and cutting are late additions to the original shrine. 1979, 233-34

9 Far these and the following objects, see Kommos

${ }^{10}$ The flat slab to the right of the horse in fig. 8 and more dearly shown in fig. 7 where the southern edge of the hearth has been temporarily removed, has been interpreted in the past as the bottom of the hearth. Although this is true for the hearth phase itself, the slab itself could have sewed during an intermediate period as a small platform in front of the pillars.
Mediterranean during both the Bronze and Iron Ages." In Minoan Crete, for instance, under certain circumstances the column seems to assume symbolic meaning, as in the miniature model from Knossos (fig. 11), which depicts three columns topped by beams upon which rest birds, perhaps doves, possibly symbolic of the deity. '2 Pillars also can be marked with sacred symbols: the four blocks of a pillar from the shrine area in the West Wing at Knossos are incised with some 29 separate signs of the

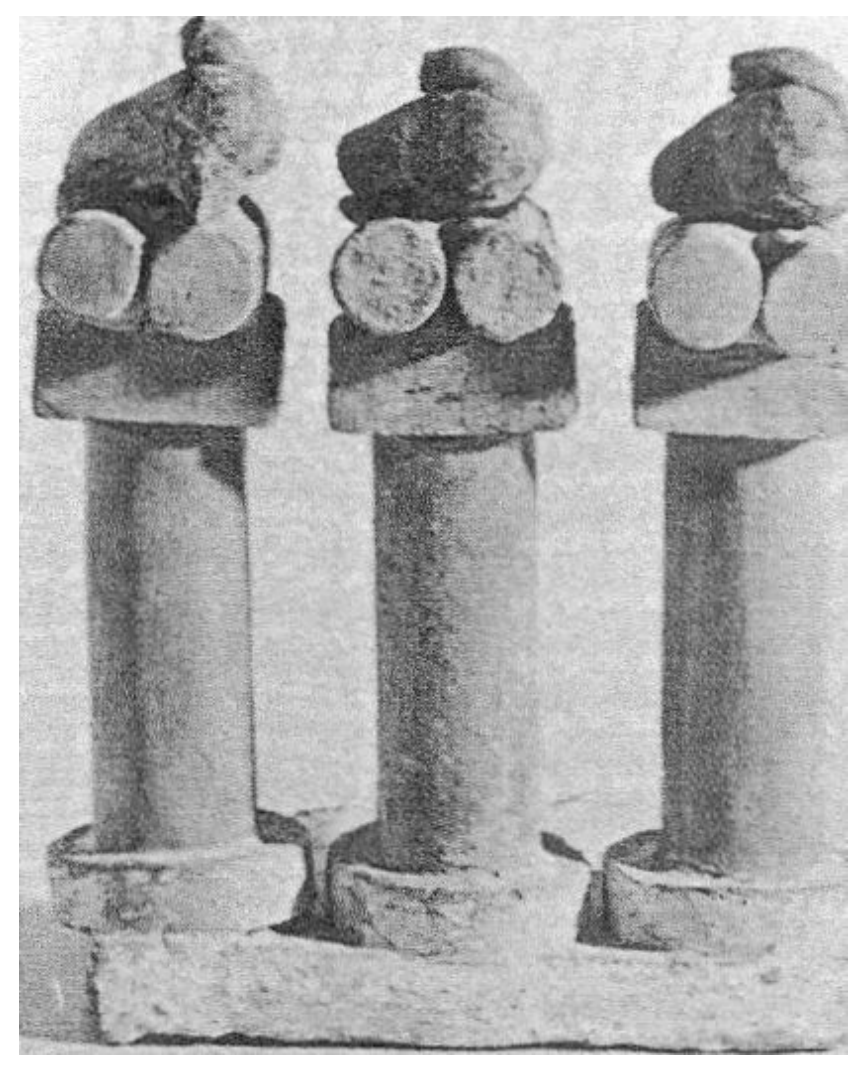

Fig. 11. Knossos, terracotta 'pillar shrine.' (After I. Sakellarakis, Herakleion Museum Guide [ 1978] 24)

${ }^{11}$ See, for instance, "Sacred Stones: Epiphanies, Signs and Forms," in M. Eliade, Patterns in Comparative Religion (London 1958) 216-38.

${ }^{12}$ The theme was developed at some length by Sir Arthur Evans in his "Mycenaean Tree and Pillar Cult," JHS 21 (1901) 99-204, asp. 138-53. Mycenaeans shared the symbolism of columns, as in the Lion Gate at Mycenae. A recent study of the Lion Gate suggests that the column and entablature may represent literally either the propylon leading to the palace or an identifiable part of the palace: M.C. Shaw, "The Lion Gate Relief of Mycenae Reconsidered," Philia Epi for George E. Mylonos (Athens 1987) 122-23. See also the following two notes. 
double-axe. ${ }^{13}$ Freestanding pillars, moreover, appear in the often clearly cultic scenes on seals and sealings. The exact function of the signs on the Knossos pillar or the significance of the pillars in the cultic scenes, however, still remain ambiguous. ${ }^{14}$

Pillars and pillar worship are also known from the Greek mainland, although they postdate the tripillar shrine from Kommos and are probably unconnected with Cretan tradition. The partly aniconic stelai of Hermes, or herms, are perhaps the best known types. One of the clearest examples involving pillars is a stele of the third century B.C. from Arcadia on which each third of the stele, defined by the separate crowning members and vertical divisions below, represents one of the nymphs, the inscription "of the nymphs" specifying the general attribution. ${ }^{15}$ The sacredness of individual stones is well attested in the second century A.C. by Pausanias (7.22.5), who describes how, at Pharae in Achaia, for instance, "Close to the image [of Hermes] stand about thirty square stones: these the people of Pharae revere, giving to each stone the name of a god. In the olden time all the Greeks worshipped unwrought stones instead of images." ${ }^{16}$ Pausanias (1.44.2) also notes a pyramidal stone from Megara, known as Apollo Carinus. Nicholas Yalouris has reviewed the evidence for such worship, especially for Arcadia, and he concludes that "the aniconic representation of deities in the shape of a column, pyramid, or square stele was common in antiquity, especially in Arcadia, which is the origin of most of the monuments ... Apollo is more specifically worshipped here in his aniconic form under the name Agyieus ..." "17

${ }^{13}$ Cf. J.W. Shaw, "Minoan Architecture: Materials and Techniques," ASAtene N.S. 33 (1971) 111, where such "masons' marks" are discussed generally. See also now S. Hood, "Mason's Marks in the Palaces," in R. Hägg and N. Marinatos eds., The Function of the Minoan Palaces (Stockholm 1987) 205-12. See infra n. 14.

${ }^{14}$ Nilsson thought that the signs may have had a sacral function, either putting the construction under divine protection or imparting to it divine strength (M.P. Nilsson, The MinoanMycenaean Religion and Its Survival in Greek Religion [New York 1971] 247). More recently, Rutkowski has considered them symbols of divinity, but he does not believe that they indicate that the pillars were considered sacred (B. Rutkowski, The Cult Places of the Aegean [New Haven 1986] 42), a view followed by Burkert (W. Burkert, Greek Religion [Cambridge 1985] 29). Concerning the columns, Nilsson 255 thought that those with part of an entablature above them might represent a shrine (a view shared by Rutkowski 37 and Shaw [supra n. 12]). Concerning depictions of Aegean freestanding columns or pillars, Nilsson 258 was inclined to believe that given the sacred baetyls, stones, and columns known to exist elsewhere in the Eastern Mediterranean (for which see here below), those in the Aegean should be considered to be sacred.

${ }^{15}$ EphArch 1911, 154. For a recent evaluation see S.G. Miller, "The Altar of the Six Goddesses in Thessalian Pherai," CSCA 7 (1974) 231-56, esp. 247-48. An interesting tapering base, of the sixth century B.C. in the Sparta Museum should also be mentioned. It is some $0.67 \mathrm{~m}$ high, perhaps depicting Menelaos and Helen on each of two broader, opposite sides. While not aniconic, the object's form is reminiscent of our single pillars
In Crete, on the other hand, there is little evidence for this type of worship of Apollo Agyieus which "developed out of the cult of the Agyieus-pillar as a fertility symbol ..."18 More common than such aniconic or schematic representations, and possibly related to the Kommos tripillar shrine, are the depictions of triads of a god and two goddesses often identified as Leto and her two children, Apollo and Artemis. The earliest sculpted figures are the well-known seventh-century bronze statues from the Temple of Apollo at Dreros. In the same tradition are those from the temple on the acropolis at Gortyn, probably also depicting the "Apollonian" triad. ${ }^{19}$ An eighth-century repoussé belt from Knossos shows the three figures within an architectural setting protected on either side by a triad of archers, a motif known from a stone relief from Chania as well. ${ }^{20}$

Such triads, it has been proposed, originate in the East, coming "to Crete and the Peloponnese from Egypt some time in the eighth century, either directly or indirectly through Phoenicia." ${ }^{21}$ Indeed, during this and the next century the Oriental influence is particularly strong and, as I have suggested in the past, the analogous presence of two figures of the Memphite triad, Sekhmet and Nefertum, with the former possibly equivalent to Artemis, set between the pillars of the Kommos shrine, is quite appropriate. ${ }^{22} \mathrm{I}$ have also argued elsewhere that there may have been a connection between Apollo and a possible ancient name for the Kommos site, Amyklaion, ${ }^{23}$ a word probably derived from a Greek transliteration of a

from Kommos, as well as that from Kition (fig. 14). See J. Boardman, Greek Sculpture. The Archaic Period (London 1978) figs. 123A-123B. For a hexagonal pillar at the Argive Heraeum thought by its excavator to be one described by Pausanias, see $\mathrm{C}$. Waldstein, The Argive Heraeum I (Cambridge 1902) 43.

${ }^{16}$ For translation, see J.G. Frazer, Pausanias's Description of Greece (London 1898) 362.

${ }^{17}$ N. Yalouris, "Problems Relating to the Temple of Apollo Epikourios at Bassai," Acta of the XI International Congress of Classical Archaeology (London 1978) Plenary Papers, Pt. 2, 89-104, esp. 100-101. I am grateful to Dr. Yalouris for bringing the article to my attention duringfhis AIA visit to Toronto in 1986. 1962) 259

${ }^{18}$ R.F. Willetts, Cretan Cults and Festivals (London

${ }^{19}$ T.H. Price, "Double and Multiple Representations in Greek Art and Religious Thought," JHS 91 (1971) 48-69, esp. 58-59.

${ }^{20}$ J. Boardman, The Cretan Collection in Oxford. The Dictaean Cave and Iron Age Crete (Oxford 1961) 138, fig. 53. The structure in each may be a naiskos, a framing relevant for our later discussion of Phoenician stelai here. For a schematic rendering of naiskos and figure see ASAtene N.S. 17-18 (19551956) 265 , fig. $60 \mathrm{c}$.

${ }^{21}$ Price (supra n. 19) 59.

${ }^{22}$ Kommos 1979, 248.

${ }^{23}$ Kommos 1977,153-54. 
Phoenician title. ${ }^{24}$ It is only appropriate then that we look further abroad for possible inspiration for our tripillar shrine.

\section{The Near East}

In reviewing briefly the evidence for Near Eastern and, specifically, Phoenician pillar worship, we can first note that in Egypt the great obelisks from New Kingdom temples (e.g., at Karnak or Luxor), ${ }^{25}$ would have been visible to visitors. The closest contact between the Greeks and Egyptians, however, postdated the first phase of Kommos Temple B when the tripillar shrine was built. The obelisks represented the primeval gods Atum (the setting sun) and $\operatorname{Re}$ (the rising sun). Occasionally the obelisks

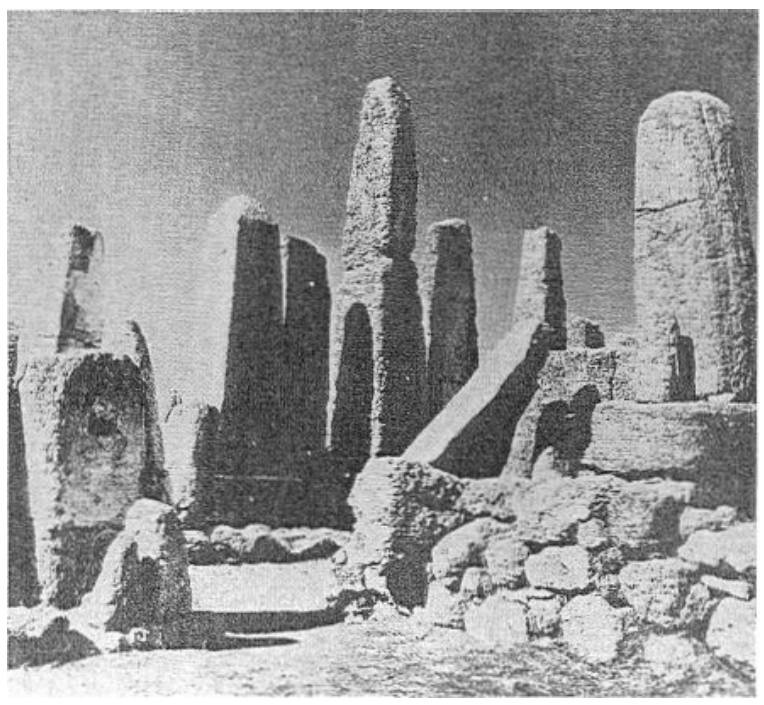

Fig. 12. Obelisks in courtyard of temple at Byblos. (After W. Culican, The First Merchant Venturers [London 1966] 27)

were believed to have been occupied by a god and thus entitled to an offering. ${ }^{26}$ In that sense they can perhaps be compared to the Phoenician/Punic pillars (see below) but more generally they seem to have served as architectural embellishments, as they were erected at temple axes and ceremonial entrances.

In the Syro-Palestinian area, the tradition of pillar worship is especially well known during the second millennium B.C. Pillars are also mentioned frequently in

${ }^{24}$ B.C. Dietrich, "Tradition in Greek Religion," in R. Hägg, The Greek Renaissance of the Eighth Century B.C. (Stockholm 1983) 85-89, esp. 87 and n. 52 (perhaps from Astort). I thank Maria Shaw for pointing this out to me. See also infra $n$. 44 and Hermary (infra n. 40, 1986).

${ }^{25}$ L. Habachi, The Obelisks of Egypt (New York 1977) 5. The form was said to have originated as the pyramidion (or Benben) at early Heliopolis. The multiple slabs set within shrines at the bases of the pyramids should also be recalled.

${ }^{26}$ Habachi (supra n. 25) 10.

${ }^{27}$ The evidence has been reviewed by C.F. the Old Testament where they are called masseba $(\mathrm{pl}$. massebot), literally standing or set-up stones. ${ }^{27}$ They have also been called baetyls or "home of the god." The Byblos shrine with its numerous pillars is perhaps the best known example (fig. 12) ${ }^{28}$ In their obviously cultic position there the pillars probably marked the sacred area where the deity might be found, and where worship and sacrifice should take place. The small shrine at Hazor reflects a similar tradition on a more intimate scale. ${ }^{29}$ There slabs or stelai with tapering tops, rather than pillars, were arranged in a semicircular fashion to form a niche at the end of a room; they appear to have been objects of worship containing the spirit of the deities. The 13th-century temple at Lachish had at its far wall, opposite the entrance, a clay bench with three projections which have been called altars possibly representing a triad of deities; the nature of the projections is vague, however, and the Late Bronze Age I (16th-15th century B.C.) date is not too helpful for our purposes. ${ }^{30}$

Pillar worship may be archaeologically traceable down into the Phoenician/Philistine culture at eighthcentury Sarepta in the form of a small, benched temple probably dedicated to Tanit-Ashtart, with a possible pillar set in front of the table of offerings. Sarepta is one of the few places in the Phoenician homeland where a firstmillennium Phoenician ritual structure can actually be inspected. $^{31}$ Of the "pillar", however, nothing save the impression of the $0.40 \mathrm{~m}^{2}$ base of the object in the cement floor remained. Apparently it had been pried loose from its place. Pritchard, the excavator, speculated that it may have been a stone baetyl, at least a meter high, or an incense altar. $^{32}$

The tradition of tapering pillars, probably reflecting Assyrian or early Syro-Palestinian tradition, is known in Asia Minor in the open-air Urartian shrines at Van, Bostankaya and, especially, in a monumental form at Altintepe. These were courtyard-like areas, open to the sky, containing an altar and/or pillars. ${ }^{33}$ The shrine at Altintepe, of the mid-eighthearly seventh century B.C., was probably related to a cult associated with the dead, and was unusually well preserved. It featured a row of four pillars, $2.30 \mathrm{~m}$ high and with rounded tops, in overall appearance quite like the Kommos examples. Projecting tenons, like those at Kommos, were set

Graesser, "Standing Stones in Ancient Palestine," BiblArch 35 (1972) 33-64.

${ }^{28}$ Graesser (supra n. 27) 58-59.

${ }^{29}$ Graesser (supra n. 27) 59-60.

${ }^{30}$ O. Tufnell, Lachish II: The Fosse Temple (London 1940) 39 and pl. LXXI.1.

${ }^{31}$ For the Sarepta structure, probably the shrine of Tanit-Ashtart, see J.B. Pritchard, Recovering Sarepta, a Phoenician City (Princeton 1978) esp. 131-38.

${ }^{32}$ Supra a. 31, 138; and J.B. Pritchard et al., Sarepta (Philadelphia 1975) 18.

${ }^{33}$ T.B. Forbes, Urartian Architecture (BAR-IS 170, 1983) figs. 44-45. 
into separate stone bases. In front of them was an altar, $0.50 \mathrm{~m}$ in diameter, with a grooved interior (fig. 13). ${ }^{34}$

Of some interest at Sarepta, and part of a local Iron Age tradition (at Beth Shan, Arad, and Tell Quasile) with Late Bronze Age precedents at Hazor and elsewhere, are the wall benches. ${ }^{35}$ The general arrangement at Sarepta of benches along the side walls, and the "pillar" on axis with offertory (the "bowl") between it and the back wall, offers a striking parallel to the arrangement at Kommos's Temple B. They may reflect a common tradition since the specific arrangement has no clear antecedents in Bronze Age Cretan shrines and evidence is accumulating to show that early Iron Age Kommos was influenced by the Phoenicians.

The tradition of wall benches and freestanding pillars is also known on Cyprus, at Enkomi in the 12thcentury shrine of the "god of the ingot." ${ }^{36}$ At Kition, in the first phase of the Phoenician temple of Astarte (1300-1000 B.C.), three main aisles led through three entrances to the holy-of-holies, an arrangement thought to reflect the three

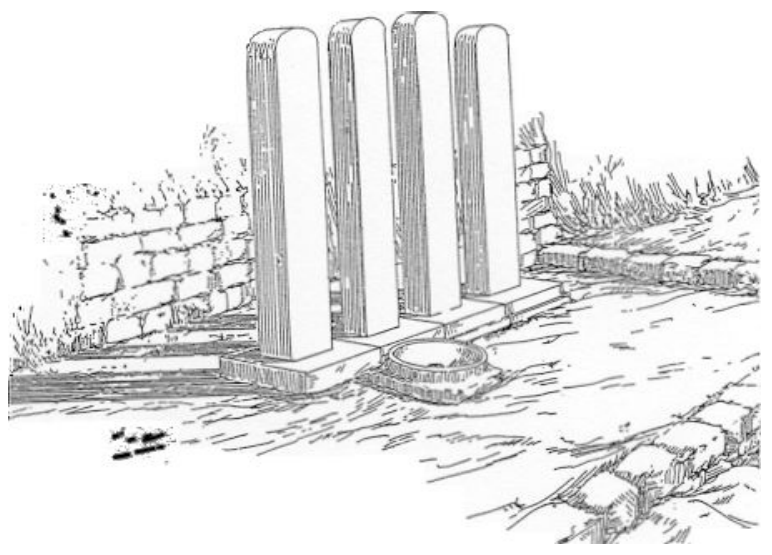

Fig. 13. Reerected, restored pillars in Altintepe outdoor shrine. (After Özgüç, Altintepe II, fig. 29)

${ }^{34}$ T. Özgüç, Altintepe II (Ankara 1969) 29-33 and figs. 29-33. I am indebted to Oscar Musarella for drawing my attention to this northern offshoot of the Near Eastern tradition, a tradition which he notes (letter of 22 May 1984) appears also at ninth-century Hasanlu in the form of a large, pointed, socketed slab next to Burned Building II. The preservation of the stela there from the first third of the first millennium B.C. helps to reinforce the likelihood of the tradition of pillars at Sarepta and those suggested (see below) for use in contemporary Cypriot Kition and perhaps at Paphos.

${ }^{35}$ Pritchard (supra n. 32) 19.

${ }^{36}$ Supra n. 35.

${ }^{37}$ V. Karageorghis, Kition (London 1976) 96-98.

${ }^{38}$ Supra n. 37, 98 .

39 Supra n. 37, 98, pl. 71 (for another version on a coin). A recent study has suggested that the three-cella arrangement may have originated in Egypt: A. Altherr-Charon, "Origne des temples à trois cellae du bassin Méditeranéen est: état de la question," AntCl 46 (1977) 389-436, esp. 433. For depictions on coins, see also B.L. Trell, "Architectura Numismatia Orientalis: A Short Guide to the Numismatic Formulae of Roman Syrian Die-Makers," NC 1970,29-46, esp. 42-43. deities worshipped. ${ }^{37}$ On either side of the central entrance, outside of the holy-of-holies, were two pillars of rubble faced by ashlar blocks, $2.20 \times 1.50 \mathrm{~m}$ (one pillar was preserved to a meter in height). The excavator connects the pillars with the Syro-Palestinian tradition, ${ }^{38}$ which was to last in the Astarte temple through its third phase (600-450 B.C.), the period during which formal benches were apparently introduced. We should also recall the wellknown depiction on a Roman coin of a tripartite cella arrangement within the Temple of Aphrodite at Paphos. Shown within the cella or forecourt is a pyramidal form usually interpreted as a sacred pillar. ${ }^{39}$ In a related tradition is a small pillar (fig. 14) from Kition (modern Larnaca), perhaps from the area of the Temple of Astarte. The tapering pillar, acquired by the Louvre in 1902, is complete and about $0.42 \mathrm{~m}$ high. On its face is a Phoenician inscription, in seventh-century style, translated as "this was made by Eshmounhillç, the sculptor, for his lord, for Reshef Shed." ${ }^{40}$ Hermary has most recently proposed that a head of the Egyptian god Bes, found along with the pillar, was affixed to it by means of a wooden dowel (fig. 14). This pillar is of particular importance for our purposes here, for the writing upon it firmly fixes its date in the seventh century B.C. and identifies the pillar form as one used by the Phoenicians.

This use of pillars in Cyprus is probably derived from the Syro-Palestinian tradition; one of the first stages in the Phoenicians' westward movement, prompted by pressures at home and especially by the Assyrians, was their establishment of major settlements in Cyprus. ${ }^{41}$ While contact between Cyprus and Phoenician cities such as Tyre and Sidon had a long history, Phoenician expansion westward to Cyprus is dated by pottery to the 10 th century B.C. at the earliest, with most estimates falling into the middle to late ninth century. ${ }^{42}$

${ }^{40}$ A. Hermary, "Deux ex-voto chypriotes reconstitués," RLouvre 34 (1984) 238-40, and "Influences orientales et occidentales sur fieonographie des divinité chypnotes $\left(\mathrm{VII}^{\mathrm{e}}-\mathrm{III}^{\mathrm{e}}\right.$ s. av. J.-C.)," in V. Karageorghis ed., Acts of the International Archaeological Symposium "Cyprus between the Orient and the Occident, 1985" (Nicosia 1986) 405-10, esp. 405-406.

${ }^{41}$ For the nature of the pressures upon the Phoenicians, see especially S. Frankenstein, "The Phoenicians in the Far West: A Function of Neo-Assyrian Imperialism," in M.T. Larson ed., Power and Propaganda: A Symposium on Ancient Empires (Mesopotamia 7, Copenhagen 1979) 263-91, esp. 269-73.

${ }^{42}$ V. Karageorghis et al., Excavations at Kition IV. The Non-Cypriote Pottery (Nicosia 1981). P. Bikai dates the Eastern pottery at the earliest to the ninth century, in agreement with Karageorghis (supra n. 37) 95-96, who also suggests, however, that there may have been Phoenicians in Cyprus at least 100 years earlier. 


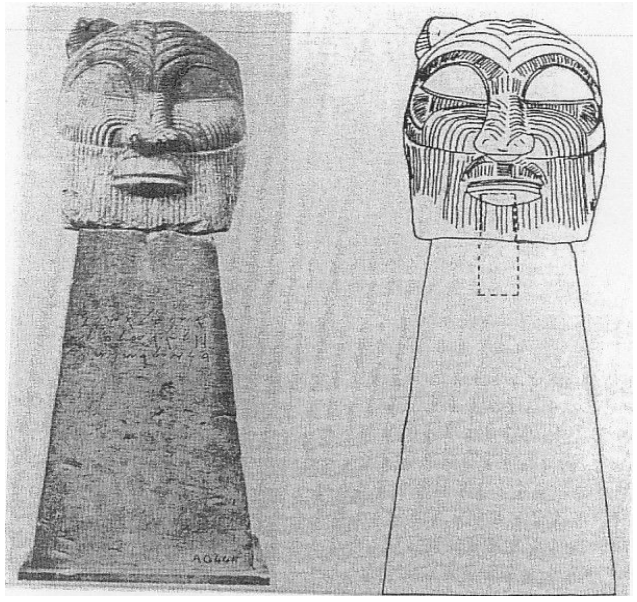

Fig. 14. Cypriot pillar, with Phoenician inscription, with Bes head as restored. (After Hermary, Influences Orientales ... [Nicosia 1986] pl. 41.1-2)

There is little sign in the East of the traditional burial grounds or tophets, known in the Punic West, where human sacrifices were often carried out. A group of 13 slabs similar to those associated with the tophets, however, has been found at Kouklia (Ancient Paphos) in Cyprus. These slabs were discovered in the Persian siege mound of 498 B.C. along with votive columns. One of the slabs displays a broken top with a projection for insertion into a base. ${ }^{43}$ It tapers very little, if any, however, and is a slab rather than a tapering pillar such as we have seen from much earlier contexts in Syria, at Kommos, and as probably depicted on the later Western stelai. ${ }^{44}$

\section{The Punic West}

The Punic West, which perhaps began to be settled by the end of the ninth century, is particularly important for our search: not only was there a clear tradition of pillar worship in the area but convincing pictorial evidence for freestanding tripillar shrines exists, even if the actual examples identified as such shrines are not entirely convincing. Actual pillars can be seen in Sar-

\footnotetext{
${ }^{43}$ I am much indebted to F.G. Maier for his help in providing information regarding these slabs (see also F.G. Maier, "Excavations at Kouklia (Palaepaphos). Sixth Preliminary Report: Seasons 1971 and 1972," RDAC 1973, 188); and to Veronica Tatton-Brown for her most helpful information.

${ }^{44}$ The term stela (pl. stelai) is used hereafter to describe a slab, often with decorative design or inscription, meant to be set upright as a marker or monument.

Other pillars and/or stelai, not dearly associated with either shrine or burial ground, have been reported recently from Hala Sultan Tekke. Some of these were inserted into soles, and two probably flanked the entrance into a building (S.

Sophocleous, Atlas des représentations chypro-archaïques des divinités [SIMA-PB 33, Göteborg 1985] 9 and ns. 26-27 [after u. Öbrink, Hala Sultan Tekké 5 (SIMA 45:5, Göteborg 1979) 15, nos. N 4014 and F 6079 and figs. 55, 56, 85]). He also mentions (p. 10) that a fourth-century inscription from Kition is concerned with stone pillars in the temple of MKL, MKL apparently being an epithet for the Canaanite/Phoenician god Reshep who was equivalent to Apollo Amyklaios worshipped in Laconia. Here
}

dinia, for instance, where a rough example was set into a socle. ${ }^{45}$ It is the series of pillars and stelai from the

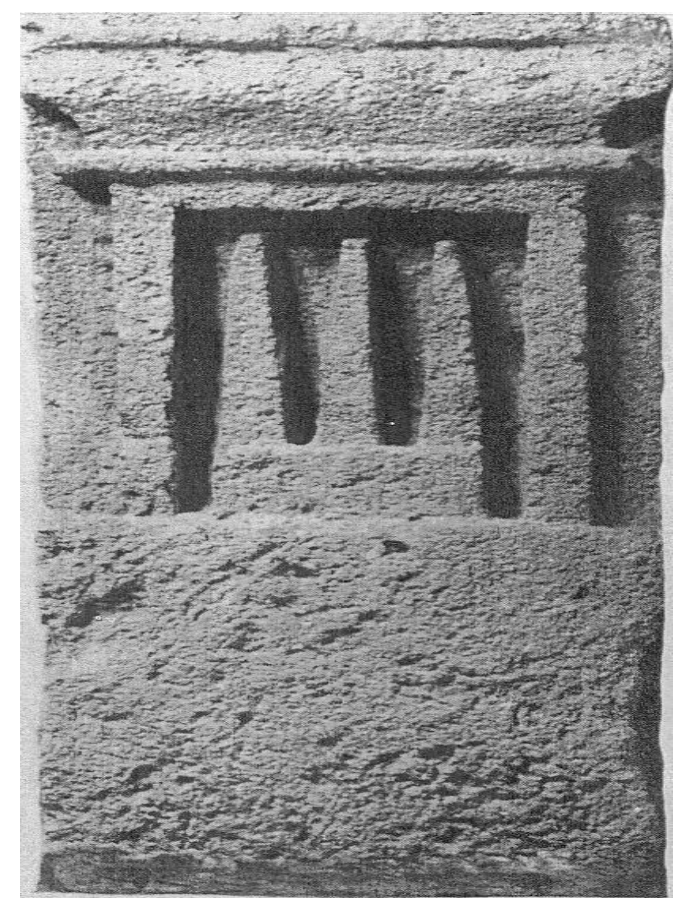

Fig. 15. Stele from Nora. (After Moscati, I fenici e cartagine (Torino 1972] 320)

Punic tophets, however, with reliefs which depict various ritual symbols and acts, that are most pertinent. Some of these pillars are single and socketed into a base; but the reliefs include depictions of groups of pillars on a base. These reliefs dearly represent pillared shrines, with one to as many as six pillars set next to one another, their sides straight or tapering. ${ }^{46}$ Some of the depictions, reminiscent of the Kommos tripillar shrine, are shown in Figures 1517. The first, from Nora in Sardinia, shows three tapering

could be a later, but parallel situation to that at Kommos, which perhaps had the ancient name of Amykaon (see supra n. 24).

${ }^{45}$ See S. Moscati, Fenici e Cartaginesi in Sardegna (Milan 1968) pl. 23; NSc 1970, Suppl. II, 287, fig. 487 (ht. 1 m); ILN 3 April 1965,19-21.

46 The range of form can best be seen in P. Cintas, "Le sanctuaire punique de Sousse," RAfr 91 (1947) figs. 67-68; also A.M. Bisi, Le stele puniche (Studi Semitici 27, Rome 1967). I am especially grateful to Shelby Brown for her detailed advice given about the Punic steal and their representations. She has also suggested that while these reliefs illustrate single, double, and triple pillars, the multiple-pillared depictions are often double two-pillar and three-pillar "sets," making four and six pillars, and even triple three-pillar sets making nine pillars in all. It seems to her that at least six and nine pillars are probably just repetitions of the basic tripillar shape. For the variety of stelai from Carthage and other sites see also P. Bartolini, Le stele arcaiche del Tophet di Cartagine (Rome 1976) passim. P. Bikai, L. Stager, S. Wolff, and others have also helped me at intervals with the Punic material. 


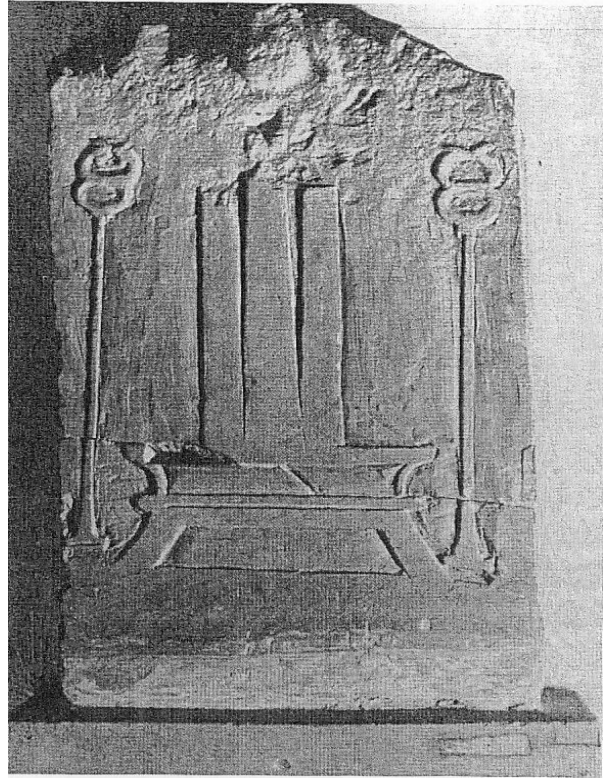

Fig. 16. Stele from Sousse. (After Moscati, I fenici e cartagine [Torino 1972] 549)

pillars set either upon or, more likely, into a base, all within a small, open, Egyptianizing naiskos (fig. 15). The second, from Sousse (Hadrumetum) in North Africa, lacks the enclosing shrine, but has a fancier, incurving base with legs, and is flanked by stands terminating in symbols like caducei (fig. 16). The pillars of the shrine, however, are very similar in appearance to those from Kommos, as are those on the stele from Lilybaeum in Sicily (fig. 17) where a worshipper or priest stands what may be an incense burner, along with probably representing Tanit (the Phoenician set above and about the tripillar shrine.

The stelai, which often marked the individual grave plots of sacrificed infants or animals substituted for the infants, ${ }^{47}$ seem to have symbolized in their depictions at least the presence and/or intercession of the deity. Their date is often difficult to determine because of poor preservation and/or lack of dear stratigraphy at the tophets. Motya, known to have been destroyed after a long and vicious siege by Dionysus of Syracuse in 397 B.C., may be helpful in this regard. If we assume, as many do, that the survivors all left subsequently to found Lilybaeum ${ }^{48}$ then the relief depicting the tripillar shrine in the Motya museum should predate the destruction. ${ }^{49}$ Also, since Lilybaeum was presumably without tophet until Motya's destruction, then the stele in our Figure 17, from Lilybaeum, is later, perhaps of fourth century or Hellenistic date. The example from Hadrumetum (fig. 16) should be dated later than 400 B.C. ${ }^{50}$

${ }^{47}$ D. Harden, The Phoenicians (London 1962) 94-95.

${ }^{48}$ Some believe, however, that some stayed on. Cf. V. Tusa, "Mozia dopo il 397 a.C.," in Mozia III (Rome 1967) 85 and Mozia VI (Rome 1970) 47.

${ }^{49}$ Kokalos 18-19 (1972-1973) pl. 11.2.

${ }^{50}$ According to the chronology suggested by L. Stager in "Carthage: A View from the Tophet," in H.G. Niemeyer ed.,

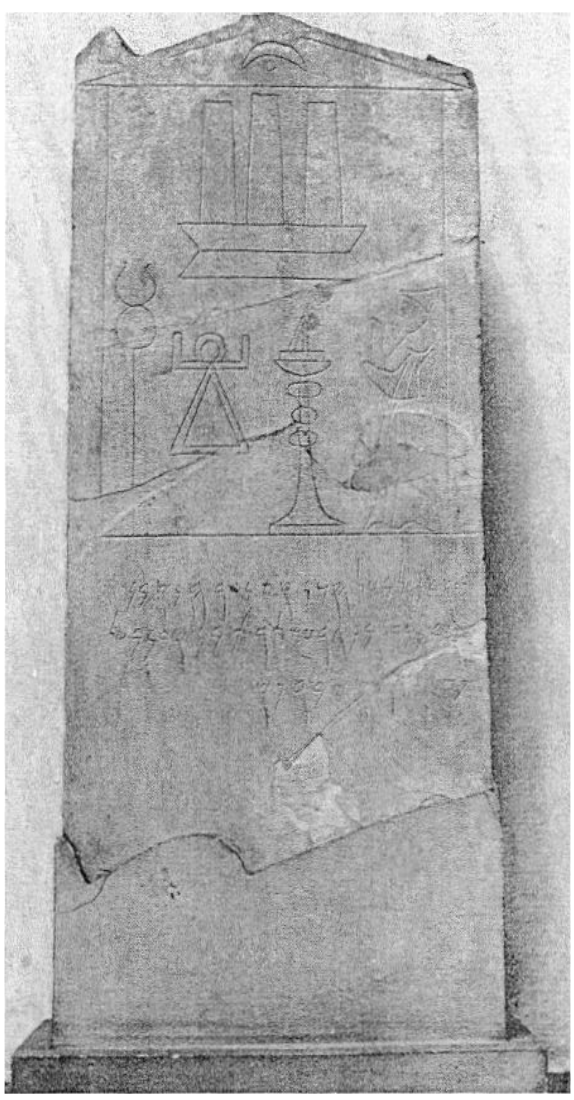

Fig. 17. Stele from Lilybaeum. (After Mosmti, I Fenici e cartagine [Torino 1972] 537)

The earliest of the Punic tripillar depiction, may be nearly four centuries later than the Kommos shrine. This hiatus between the appearance of the tripillar shrine in the East and in the West should probably not be of major concern. Future excavation may reduce the gap, perhaps even revealing shrines depicted on Eastern stelai, a tradition so far known only in the West. The custom, therefore, of erecting such stelai would postdate the erection of the actual shrines.

The belief that these stelai depict actual shrines has led to a number of identifications, of varying persuasiveness, of shrines on Punic sites. Five cases are described and interpreted here, four on islands settled by the Phoenicians. So far no examples have been reported from North Africa, perhaps the most likely place for them to occur. One shrine has been identified in Syria, the homeland, and restored on the basis of the reliefs we have been

examining.

Phönizier im Westen (Madrider Beiträge 8, Mainz 1982) 155-66, henceforth abbreviated here as $P I W$. According to Shelby Brown, depictions of tripillar shrines at Carthage are unusual, although a few of the earlier reliefs do illustrate them (M. Hours-Miédan, Les représentations figurées sur les stèles de Carthage [CahByrsa 1, 1951] esp. pl. IVa). 


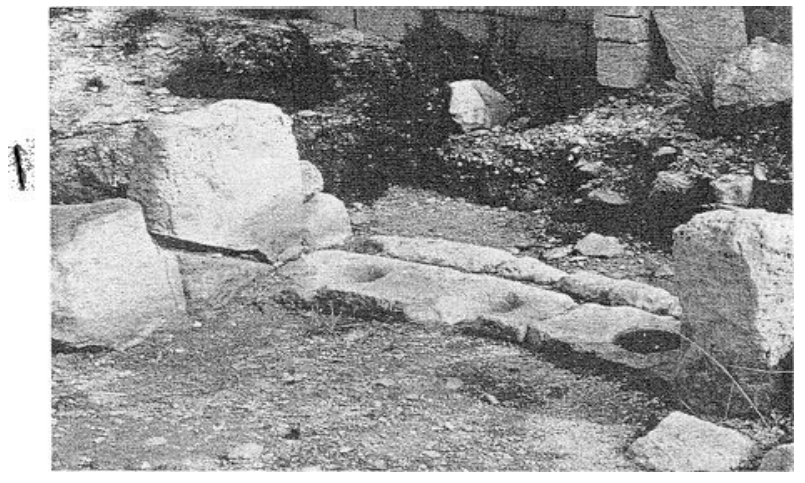

Fig. 18. Possible tripillar shrine from Tas Silg sanctuary at Malta. (Courtesy Herb Stoval)

The first example of an alleged pillared structure is at Tas Silg in Malta, installed at the rounded end of the apse of a reused prehistoric building (fig. 18). ${ }^{51}$ The bowllike cuttings in the wall blocks have been interpreted as More seriously, the holes do not look like sockets, which would be cut with straight sides, but rather like receptacles for some unknown use (cf. fig. 9). Another possibility is that they were for door pivots, but even then the deep central "pivot socket," rather than a shallower socket for a locking device, does not make sense.

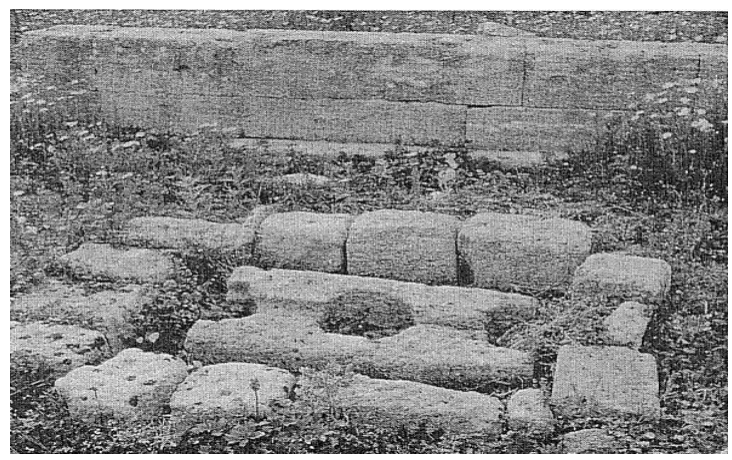

Fig. 19. Possible tripillar shrine from Motya. (Courtesy Birgitta Wohl)

A second candidate for a tripillar structure was reported by Vicenzo Tusa from within the Capidazzu, or sacral area, at Motya, on a small island off Sicily, dating to the fifth century B.C. or later (fig. 19). ${ }^{52}$ This curious

${ }^{51}$ For the original excavation of the building, see three reports, M. Cagiano de Azevedo et al., Missione archeologica italiana a Malta, in reports published in 1967, 1968, and 1969, Università degli Studi di Roma, each after the year that the work took place. They also identify elsewhere in the building, in the center of its cella $(1969$, p. 118) a "sacred threshold" with three notches designed, they think, for three vertical elements. I have not seen the block (nor is it well illustrated) but I wonder if it is simply a threshold with cuttings for two pivots with the usual central loddng device between them. This attribution was later incorporated into a study by A. Ciasca, who restored the projecting elements into the bowl-like depressions illustrated and discussed here in the text ("II tempio fenicio di Tax-Silg, una proposta di ricostruzione," Kokalos 22-23 [1976-1977] 169, fig.

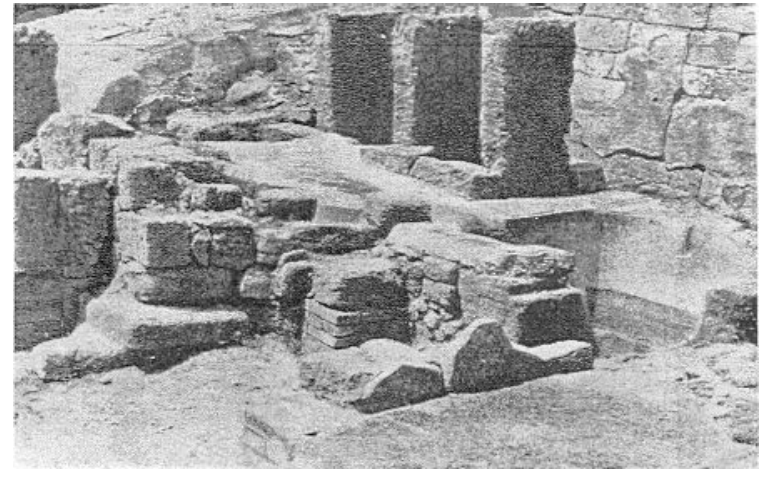

Fig. 20. Possible tripillar shrine from Segesta, Sicily. (After Famà in SicArch 13 [1980] fig. 4)

sockets for pillars. The identification seems to me doubtful. First, it seems strange that the pillars would not have been set within the reused building, but rather on an exterior wall, which would expose them to the outdoors. structure consists of a single limestone block with a central, deep, round cutting joined by two shallow channels to two other rounded cuttings, one on either end of the block. Both end cuttings extend the depth of the block, unlike the shallower central cutting. Curiously the end cuttings are incomplete, suggesting that another block or, perhaps, a wooden framework had supported the wooden or stone pillars thought to have been set into the cavities. $^{53}$ A single block with cuttings (preferably rectangular or square) would have been a more practical solution. This leaves the purpose of the channel unexplained and the whole proposal remains unconvincing.

Two other possible examples are reported again by Tusa, now in Sicily. In each case three rectangular slabs were set on edge upon what can be reasonably identified as an altar, the first at Solunto (ancient Segesta) and the second at Selinute (Selinus). ${ }^{54}$ The former (fig. 20), with the "three baetylic pillars of the Punic religion," 55 was located in a sacral area where sacrifice was undoubtedly made in connection with a basin found filled with animal and fish bones, a tradition lasting there from ca. 400 B.C.A.D. 200. The "baetylic" nature of the vertical slabs was reemphasized in a subsequent study. ${ }^{56}$ The other and quite

2). I am grateful to Herbert S. Stoval who inspected and photographed the Tas Silg Sanctuary for me in 1984.

${ }^{52}$ V. Tusa, in Mozia I (1964) 39-40, figs. 6-7, pls. vi, xxxi; VI (1970) 46-47; VIII (1973) 31 (for the possible fourthcentury date). I am much indebted to Birgitta Wohl for her photographing this unusual base during a visit in 1984 .

${ }^{53}$ Mozia I (1964) 40.

${ }^{54} \mathrm{~V}$. Tusa, "Testimonianze fenicio-puniche in Sicilia," Kokalos 10-11(1964-1965) 589-602; "Aree sacrificali a Selinunte e a Solunto," Mozia II (Studi Semetici 19, Rome 1966)148-53.

${ }^{55}$ Tusa 1964-1965 (supra n. 54) 594.

56 M.L. Famà, "L'area sacra con altare 'a tre betili' di Solunto,' SicArch 13 (1980) 7-42. Neither of the two explains why, in comparison with the Phoenician reliefs which supplied the visual comparison, the slabs are so far apart, nor exactly how they

were

found. 


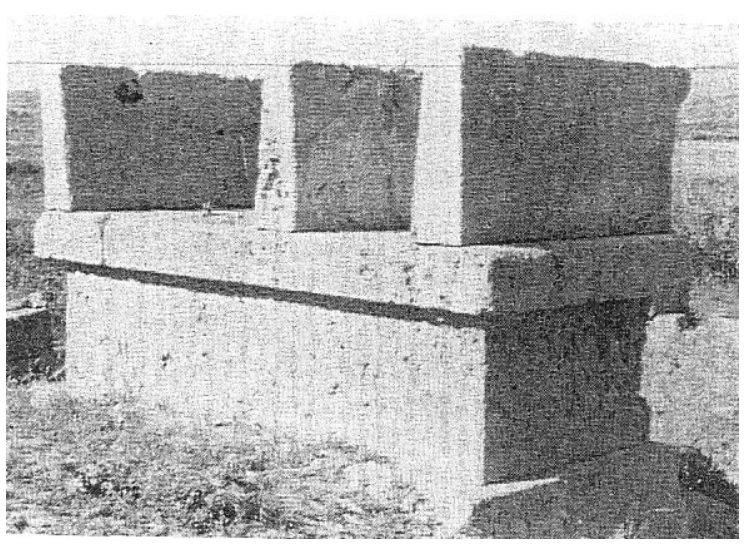

Fig. 21. Possible tripillar shrine from Selinus, Sicily. (After Famà in SicArch 13 [1980] fig. 63)

similar example is that reported from the sanctuary of Demeter Malophoros in Selinus with tapering slabs set on their broadest edges on a large stone altar (fig. 21). Once again, however, we cannot be certain that the slabs were found exactly as illustrated, although their tapering shapes $^{57}$ do suggest the proposed arrangement.

A fifth structure, in the Phoenician homeland at Amrit, is actually a small temple perhaps of the thirdsecond century B.C., known as Ma'abed d'Amrit (fig. 22) 58. It was built in the center of a large enclosure, bordered by porticoes, and placed high upon a podium carved from bedrock. Ionic, prostyle, and distyle features, as well as two projecting bases in the porch near the columns, have been restored with elaborate incense burners somewhat like those in our Figure 17. Combining the clearly proven naiskos form of the temple with the tripillar reliefs, Lézine has restored on the temple's interior a tripillar arrangement even though the pillars themselves were not found. He acknowledged, however, that the interior may have held statues rather than pillars.

\section{PHOENICIANS IN CRETE}

Although contacts between the Aegean, Cyprus, and the Syro-Palestinian coast were interrupted shortly after the unsettled, often catastrophic, events of the late 13th century B.C., they were renewed not long afterward, perhaps beginning with the enterprise of Euboean and/or

57 Famà (supra n. 56) 39-40; one of the preliminary notices by Tusa quoted from Kokolos 18-19 (1972-1973) 409.

58 A. Lézine, Architecture punique (Paris 1962) esp. 19-25. See also A.M. Bisi, Le stele puniche (Studi Semitici 27, Rome 1967) 32 and pl. III.2.

${ }^{59}$ M.R. Popham, L.H. Sackett, P.G. Themelis et al., Lefkandi I, The Iron Age (London 1980) 363.
Eastern traders during the late 11th century, and still later, during 900-825, with Lefkandi on Euboea prospering when "no other state on the mainland [of Greece] has, to date, shown evidence of equal initiative or wealth." ${ }^{59}$ This type of interchange was to result in the establishment in the Levant of an apparently joint Cypriot and Euboean effort to found a trading post at Al Mina in Syria ca. 825 B.C., ${ }^{60}$ or somewhat later, about the time that Kommos's Temple B was founded. These events occurred at about the same time that Phoenician expansion to the west was already underway, apparently including a series of unguent factories perhaps originating at Kition on Cyprus, on Crete, and on the Dodecanese islands of the eastern Aegean. ${ }^{61}$ According to tradition, Carthage was founded in 814 B.C., although, to date, the earliest material from there is later. ${ }^{62}$

The timing and effects of this movement as it touched upon and influenced various parts of the Aegean, in particular Crete, have been the subject of considerable interest lately as archaeological discoveries

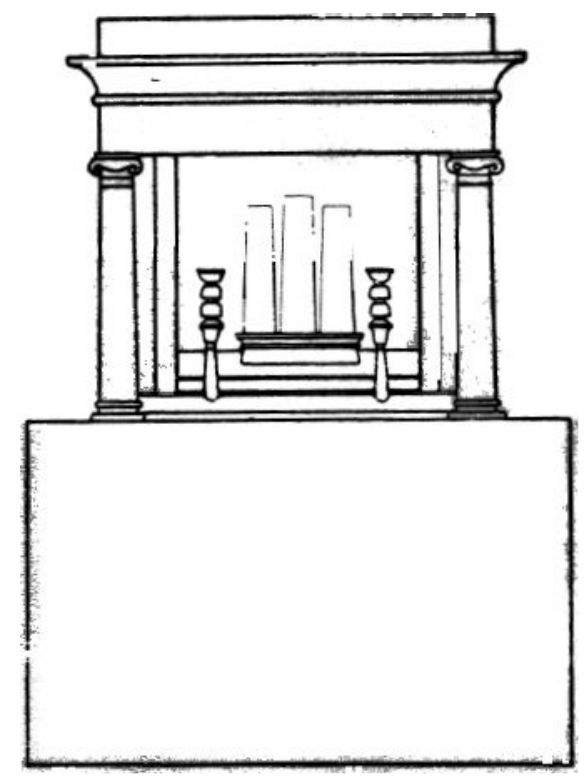

Fig. 22. Possible tripillar shrine, Ma'abed d'Amrit, Syria (After Lézine, Architecture punique [Paris 1962] figs. 10-11)

${ }^{60}$ Supra n. 59, 367, with references. See also M. Popham et al., "Euboean Exports to Al Mina, Cyprus, and Crete: A Reassessment," BSA 78 (1983) 281-90.

61 J.N. Coldstream, "Greeks and Phoenicians in the Aegean," in PIW (supra n. 50) 261-75, esp. 268-69.

${ }^{62}$ Stager (supra n. 50) 156-57. 
have prompted debate. The presence of North Syrian craftsmen resident in Crete has been argued, especially by Boardman, on the basis of Orientalizing jewelry from Knossos and of armor, such as the famous bronze shields from the Idaean Cave, although Lembessi and, more recently, Muhly have opposed the suggestion. ${ }^{63}$ An important point of controversy in this discussion has been the date of the earliest Phoenician visits to Crete, based on the Phoenician objects found in Cretan Geometric contexts, usually in caves and tombs. Considerable range of opinion has been expressed, for instance, in reference to the date of a Phoenician bronze bowl from the Tekke cemetery at Knossos. It has an inscription ("cup of Sama, son of L," as translated by Frank Cross) which has been dated variously to the 10th century B.C. (by Guzzo and Sznycer), to the 11th century (by Cross and Puech), and to the 12th-11th century (by Negbi). ${ }^{64}$

Coldstream recently charted these variations of scholarly opinion, and he clarified the roles of the Easterners as artisan and trader, suggesting that there were two phases of contact. ${ }^{65}$ The first occurred in the early ninth century B.C., after earlier visits had established contact, even if sporadic, with Aegean centers such as those mentioned above. The second phase, which brought trade in unguents and resident craftsmen, overlapped with the massive organized Phoenician colonial movement to the west which began in the last quarter of the ninth century. Recent excavation at Knossos led to the important discovery of four ninth-eighth century Phoenician pots, possibly for unguents, in tombs of the North Cemetery. Of these, two are round-mouthed jugs, one bichrome and the other red-slipped, a juglet, as well as a trefoil-lipped jug, also red-slipped. ${ }^{66}$ This material strengthens the view that Phoenicians were present on Crete.

63 J. Boardman, The Greeks Overseas: Their Early Colonies and Trade ${ }^{2}$ (London 1980) 37, 56-59; A. Lembessi, "The Fortetsa Gold Rings," BSA 70 (1975) 169-76, esp. 173 and n. 49. A valuable general review of the situation then is J.D. Muhly, "Phoenicia and the Phoenicians," in Biblical Archaeology Today (Jerusalem 1985) 177-91, a follow-up study to his "Homer and the Phoenicians: The Relations between Greece and the Near East in the Late Bronze and Early Iron Ages," Berytos 19 (1970) 19-64. See, concerning Eastern craftsmen in Crete but elsewhere as well (e.g., Attica), also Coldstream (supra n. 61) 266-68.

${ }^{64}$ In order, M. Sznycer, "L'inscription phénicienne de Tekke, près de Cnossos," Kadmos 18 (1979) 89-93; F. Cross, "Old Canaanite and Early Phoenician Scripts," BASOR 238 (1980) 1-20, esp. 15-17; E. Puech, "Présence phénicienne dans les îles à la fin du Il ${ }^{\mathrm{e}}$ millénaire," RBibl 1983, 365-95, esp. 389; O. Negbi, "Evidence for Early Phoenician Communities on the Eastern Mediterranean Islands," Levant 14 (1982) 179-82. A recent survey of imported Syro-Phoenician metal cups suggests a range of the ninth through the seventh centuries (B. Borell, Attisch geometrische Schalen [Mainz 1978] 95). Maria Guzzo, "Iscrizioni semetiche di nord-ovest in contesti greci e italici (XVII sec. a.C.)," DialArch 5 (1987) 13.

\section{KOMMOS TEMPLE B}

With this background in mind, we can now return to the shrine in Temple B at Kommos and speculate on its origin, use, and significance. First, its context leaves little doubt as to its sacral character. Second, at least its first period of use (ca. 800-760 B.C.) coincides with the second "phase" of the Phoenicians' westward movement. Third, without contemporary local Cretan (or mainland) evidence to suggest that the use of pillared structures is indigenous, we can legitimately search for parallels abroad. There, the remarkable correspondence between the depictions on the later Phoenician funerary stelai and the Kommos shrine strongly suggests that the former may derive from a tradition of earlier shrines similar to that at Kommos, a tradition also reflected in the Phoenician pillar from Kition, whether with or without the Bes attachment. The tripillar structure at Kommos is as recognizably foreign as the imported Cypriot/Phoenician wares are at Knossos.

Further support for a Phoenician presence at Kommos is forthcoming from contexts in Temples A and early B, where many fragments-over 200-of Phoenician pottery have appeared ${ }^{67}$ Only a few of these (e.g., C3134 and C6451 in fig. 23) derive from the limited soundings made within the temples. Most originated in the dumps outside, some to the west $(10 \%)$, others to the east in front of the temples $(30 \%)$, and most from downhill, to the south and southeast $(60 \%)$, where vast amounts of material were discarded during temple cleanups. Broadly speaking, the chronological range of the Phoenician pottery is from the founding of Temple A (late 10th century) through the end of Temple B's phase 1 (ca. 750 B.C.), with a more conservative estimate beginning during the second phase of Temple A (ca. 875-800 B.C.) and extending to perhaps 760 B.C., a period of perhaps a century or less. ${ }^{68}$

${ }^{65}$ Coldstream (supra n. 61).

${ }^{66}$ J.N. Coldstream, "Cypriaca and Cretocypriaca from the North Cemetery of Knossos," RDAC 1984, 122-37, esp. 123 and fig. 1.

${ }^{67}$ For references to earlier suggestions in our preliminary reports, see Kommos 1980, 250 n. 130; 1981, 188 n. 65 ; 1982-1983, 278-79, ns. 51-52 there which mention that we may have Western Punic as well. The following account of the Phoenician pottery is a tentative statement that will be brought up to date in the future. I am indebted to Peter Callaghan for his advice, and we are particularly obliged to Eliezer Oren who visited Kommos during a brief weekend in the spring of 1986 and not only confirmed the identification but gave us valuable advice concerning both typology and chronology. Oren also made numerous helpful suggestions about the sections of this text dealing with Near Eastern material.

${ }^{68}$ No fragments can definitely be attributed to Temple $\mathrm{Al}$, although some may be from it. Concerning early Temple B, while it is dear that sherds occurring in contexts postdating A2 belong to it, many also may be from Temple B1, within which was found $\mathrm{C} 3134$ in fig. 23. 


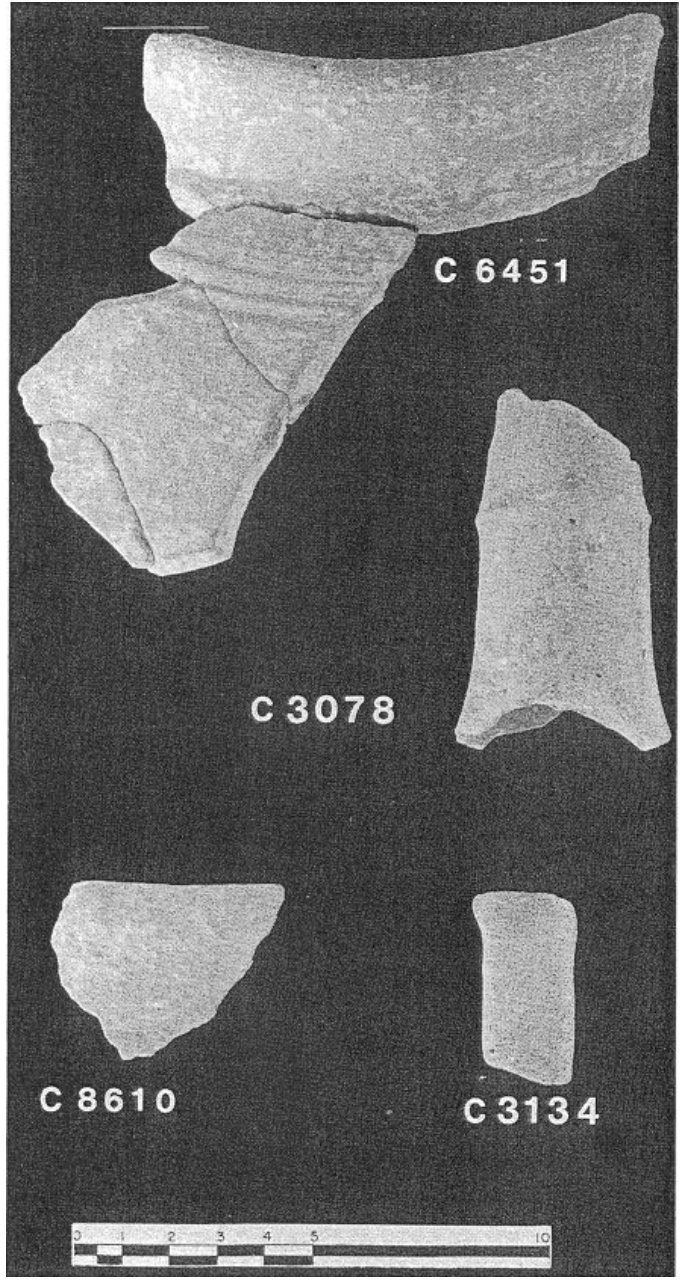

Fig. 23. Phoenician pottery from Temples A and B

The vessels are mostly amphorae. The first type, according to Eliezer Oren, is the "pithoid jar," a large, thick-walled, ovoid shape with a collared rim, e.g., C6451 $1^{69}$ in Figure 23. Comparative material in East Mediterranean contexts suggests that this class was produced as late as the ninth century B.C. Type 2, the socalled "torpedo" jar (as C8610 in fig. 23), apparently first

${ }^{69}$ C6451 is linked by joins to Temple A2; C8610 is linked to Temple A2 by a figurine join; $\mathrm{C} 3134$ was found in B1; C3078 is from a later dump south of the temples.

${ }^{70}$ This represents only one of a number of traditions carried westward from the Phoenician homeland. Among others known archaeologically: cremation graves, red-slipped ware, the Sign of Tanit, terracotta protomai, and glass pendants as well as masks. Cf. J.B. Carter, "The Masks of Ortheia," AJA 91 (1987) 365 n. 39.

${ }^{71}$ The shrine could also have been raised up for reuse from A2, built at a lower level. Or, even now there could still be an unexcavated earlier center of worship below the shrine.

open buildings and the later Punic reliefs (figs. 15-16) ${ }^{75} \mathrm{In}$ this regard, Moscati's image of a Phoenician shrine is apt: "The temples usually consisted of sacred precincts in the appears in the ninth century B.C. There are a few globular flasks among the Levantine wares, for instance C3078, as well as a handle (C3134), adding some variety to the lot (fig. 23).

The connection with Phoenicia seems clear and allows for some conclusions to be proposed, the first being that the tripillar shrine is at least inspired by the Phoenician models and may even have been made by the Phoenicians using readily available building materials at Kommos. If the above proposal is correct, then the example from Kommos is the first of its kind in the Aegean. ${ }^{70}$

Other aspects of the shrine can be explored. For instance, from the pottery we can learn that the Phoenicians' contacts with Kommos peaked during phase A2 (875-800 B.C., based on the local wares), a time when this watering and trading point on the coast served for occasional, convenient stopovers for weary travelers, and where both ships' personnel and local inhabitants might worship. Perhaps people from inland Phaistos and other, still undiscovered, Iron Age centers in the Messara celebrated certain feast days there. Travelers by sea could also have used the site as a staging point for trips to the interior, perhaps to the Idaean Cave in the high mountains to the north where much Eastern-influenced work has been discovered. In time, prosperity led to the replacement of the tiny first Temple A by a larger and better appointed structure (B) in the same style. Temple B was also to feature the shrine, ${ }^{71}$ intended, if the theory about the Phoenicians is correct, to incorporate the gods' spirits as did those in the homeland and/or the new colonies. ${ }^{72} \mathrm{We}$ do not know, of course, what each pillar at Kommos may have represented, any more than we understand those in the western Punic contexts; but if each designates a separate god then perhaps a trinity such as Baal, Ashera and Astarte was intended, ${ }^{73}$ or Tanit, Ashera and Astarte who, while being worshipped individually, were also worshipped in combination as one. ${ }^{74}$

Both Temples A and B, the latter larger and with a central pillar at the eastern, open end, probably appeared from that side rather like a naiskos. Perhaps this overall appearance is recalled in the structures shown in the Eastern-influenced Cretan depictions of divinities within

72 The Kommos shrine is small, perhaps even "miniature" if compared to the known Eastern pillars (fig. 12) and the relative proportions of the shrines in the Western relief (fig. 17).

${ }^{73}$ The concept of a trio of gods was shortly to be adopted by the Greeks from the East (supra n. 19). The specific trio was suggested by Lawrence Stager in conversation with the author. Baal was often a storm god, Ashera a goddess of the sea, Astarte goddess of love and war.

${ }^{74}$ For a recent treatment of the complicated issue of the three, see Carter (supra n. 70) 378. and W.A. Maier, III, Aserah: Extrabiblical Evidence (Harvard Semitic Monographs 37, Atlanta

1986).

open air. In the center was a small chapel, or betyl, or a chapel containing a betyl, in front of which was a 
sacrificial altar. A sacred fountain or bowland [an asherah] completed the sanctuary ...." 76

On the other hand, if we judge from the relative scarcity of Phoenician pottery in Temple B, Phoenician use of the temple may have been short-lived. Phoenicians probably gradually stopped coming to Kommos. The unbroken local ceramic sequence, however, shows that worship and ritual banqueting continued, perhaps even toward the end of Temple B's Phase 1. Not long after, the shrine was embellished with both local and exotic
75 An unusual Archaic seventh-century temple at Vroulia in Rhodes may echo a form similar to that of Kommos Temple B. The building seems to have had two rooms, the first large, one really an open porch with antae on either side. The second, smaller space was entered via a step up on either side of a central structure that may have been more like an altar, five courses high, rather than the pillar suggested at Kommos. Along the rear wall was a raised bench. See K.F. Finch, Fouilles de Vroulia (Rhodes) (Berlin 1914) 8-12 and pl.1. At Sukas in Phoenicia, a seventh-century Greek temple, facing east, was open, and apparently with a single column in antis, a plan not unlike that of our Temple B.

At the western end of the room was found a disintegrated slab with two artificial round holes (mortices?). This building was constructed, as Kommos Temple C, upon an area once sacred to the Phoenicians (P.J. Riis, Sukas I (Copenhagen 1970] 57, fig. 18).

offerings such as the shield and bronze and faience figurines (fig. 4). Later, perhaps by 630 B.C., and as accumulation on the floor built up, the shrine was partially covered and became part of a hearth. By then the last vestiges of Oriental presence were lost and the role of foreigners in the local sanctuary ceased.

DEPARTMENT OF FINE ART

UNIVERSITY OF TORONTO

TORONTO, ONTARIO

M5S 1A1 CANADA

76 S. Moscati, The World of the Phoenicians (London 1968) 40. The chapel, in our case, could be B, open to the east. Before the pillared shrine is a small hearth for sacrifice (the altar); behind it, the sacred wooden bowl. If, however, the "bowl" were really a wooden column or post, a possibility suggested earlier in the text, then it could also be interpreted as the Asherah or sacred wooden pillar that, as known from biblical tradition, stood upright near the sacred stone pillars (massebot). See also the text here and Carter (supra n. 70) 376, who recently proposed that the Ortheia sanctuary at Sparta gained its name from the upright wooden object (Asherah) brought by Phoenicians who founded the sanctuary there. Similar wooden figures, xoana, characterized numerous early Greek shrines (cf., for instance, W. Burkert, Greek Religion [Cambridge 1985] 90-92). 